Article

\title{
Comparative Phytochemical Profile, Antioxidant, Antimicrobial and In Vivo Anti-Inflammatory Activity of Different Extracts of Traditionally Used Romanian Ajuga genevensis L. and A. reptans L. (Lamiaceae)
}

\author{
Anca Toiu ${ }^{1,+}$, Andrei Mocan ${ }^{2,+}+\mathbb{D}$, Laurian Vlase ${ }^{3, *} \mathbb{C}$, Alina Elena Pârvu ${ }^{4}$, \\ Dan Cristian Vodnar ${ }^{5}$ (D), Ana-Maria Gheldiu ${ }^{2}$, Cadmiel Moldovan ${ }^{2}$ and Ilioara Oniga ${ }^{1}$ (D) \\ 1 Department of Pharmacognosy, "Iuliu Hațieganu” University of Medicine and Pharmacy, \\ 400337 Cluj-Napoca, Romania; ancamaria_toiu@yahoo.com (A.T.); ioniga@umfcluj.ro (I.O.) \\ 2 Department of Pharmaceutical Botany, "Iuliu Hațieganu” University of Medicine and Pharmacy, \\ 400337 Cluj-Napoca, Romania; mocan.andrei@umfcluj.ro (A.M.); Gheldiu.Ana@umfcluj.ro (A.-M.G.); \\ moldovan.cadmiel@yahoo.com (C.M.) \\ 3 Department of Pharmaceutical Technology and Biopharmacy, "Iuliu Hațieganu" University of Medicine and \\ Pharmacy, 400337 Cluj-Napoca, Romania \\ 4 Department of Pathophysiology, "Iuliu Hațieganu” University of Medicine and Pharmacy, \\ 400337 Cluj-Napoca, Romania; parvualinaelena@yahoo.com \\ 5 Department of Food Science, Faculty of Food Science and Technology, University of Agricultural Sciences \\ and Veterinary Medicine, 400372 Cluj-Napoca, Romania; dan.vodnar@usamvcluj.ro \\ * Correspondence: laurian.vlase@umfcluj.ro \\ $\dagger$ These authors share the first authorship.
}

Received: 19 March 2019; Accepted: 20 April 2019; Published: 23 April 2019

check for updates

\begin{abstract}
Several Ajuga species are used in Romanian folk medicine for their antioxidant, antimicrobial and anti-inflammatory properties, to treat pain, fever or arthritis. Still, the active compounds responsible for these effects and their mechanism of action are scarcely known. This research was designed to investigate the phytochemical profile (e.g. iridoids, polyphenolic compounds, phytosterols), as well as the biological potential (antioxidant, antibacterial, antifungal, anti-inflammatory properties) of two selected Ajuga species collected from different regions of Romanian spontaneous flora. The main compounds identified in $A$. reptans aerial parts extracts were 8-O-acetylharpagide, isoquercitrin and $\beta$-sitosterol, whilst in $A$. genevensis were 8-O-acetylharpagide, luteolin and campesterol. The extracts were screened for their antioxidant potential using different methods (DPPH, TEAC, EPR) and the results showed a good activity, in accordance with the polyphenol content (18-26 mg GAE/g dw). The antifungal activity on the tested strains was good. The determination of few parameters linked with the inflammatory mechanism allowed the assessment of in vivo anti-inflammatory potential. Ajuga reptans and A. genevensis ethanol extracts had anti-inflammatory activity through lowering the oxidative stress, phagocytosis, PMN and total leukocytes. The best anti-oxidative and anti-inflammatory activity was observed for the Ajuga reptans $100 \mathrm{mg} \mathrm{dw} / \mathrm{mL}$ extract when compared with diclofenac, thus the dose could be correlated with the pharmacological effect. These findings provide substantial evidence that both selected Ajuga species have the potential to be valued as sources of phytochemicals in effective anti-inflammatory herbal preparations.
\end{abstract}

Keywords: Ajuga genevensis; A. reptans; polyphenols; iridoids; sterols; anti-inflammatory 


\section{Introduction}

Over the last decades, medicinal plants have historically proved to be a valuable source of drug development candidates due to their important reserve of bioactive compounds [1]. In order to obtain new herbal medicines with important pharmacological properties, the secondary metabolites found in plants are excellent candidates. For example, omnipresent in vegetal products and important component of human nutrition, phenolics with antioxidant effects are of major interest for their valuable promising pharmacological properties [2]. Yet, numerous herbal products are empirically employed with no accurate evidence of therapeutic effects or lack of toxicity and usually their traditional importance is considered an evidence of safety and efficiency. Phytochemicals are biomolecules formed in plants, that occur in herbal drugs or phytopharmaceuticals, bioactive compounds which could lower the risk of certain disorders [3]. In this context, in order to obtain new herbal preparations, additional investigations into unexplored herbal products used in phytotherapy are required.

Phytosterols are found in medicinal and edible plants and campesterol, $\beta$-Sitosterol and stigmasterol prevail in the class of active compounds. They are also present in numerous vegetables, seeds and their oils [4]. Several studies showed the beneficial effects of sterols from plants on serum cholesterol levels $[5,6]$. The well-documented potency of phytosterols in decreasing serum cholesterol levels has led to the development of phytosterol-enriched herbal drugs or dietary supplements. On the other hand, research interest in the role of phytosterols at dietary levels achieved by consuming food items (herbal preparations, dietary supplements) which are naturally rich in phytosterols, is also increasing [7].

Fifty species and about 300 taxa are included in Ajuga genus from Lamiaceae. Many species are widespread in Asia, Europe or Africa. The herbaceous flowering plants have opposite leaves and 5-50 cm tall [8,9]. Many Ajuga species have been used as a traditional medicine for the treatment of inflammation, pain, diabetes, hypertension or gastrointestinal disorders [10]. Recent studies have demonstrated their efficacy as anti-inflammatory agents [11,12], antioxidant, cytotoxic [13], antimalarial [10], hypolipidemic [14], analgesic [15,16], anabolic, antibacterial, antifungal, cardiotonic, hepatoprotective agents [17]. It has been reported that many species of Ajuga are rich in diterpenes, iridoids, flavonoids, anthocyanins, ecdysteroids, essential oils [12,13,18-21].

Ajuga genevensis L. (blue bugle, blue bugleweed or Geneva bugleweed) is a pubescent plant widespread in many countries of Europe. "Suliman" is the Romanian name of the species and traditionally is used for sedative, antihemorrhagic and anti-inflammatory effects, as well as for its wound-healing and epithelization capacity in topic remedies [22]. Also, the plant is used for its remarkable property to precipitate the proteins from digestive tract, in treatment of diarrhoeal diseases.

Ajuga reptans L. (bugleweed, bugle or common bugle) is a flowering plant native to Europe. "Vineriţă" is the Romanian name of the species and the antioxidant and antimicrobial properties shown previously are linked with the presence of polyphenolic or iridoidic compounds [23].

In this regard, continuing our research on traditionally used Ajuga species [12], comparative phytochemical determinations of polyphenols, phytosterols and iridoids from Ajuga genevensis and A. reptans aerial parts extracts, as well as the evaluation of their antioxidant, antimicrobial and in vivo anti-inflammatory effects were performed.

\section{Results and Discussion}

\subsection{The Quantification of Total Bioactive Compounds}

Methanol and ethanol have been proven as effective solvents for extraction of phenolic compounds. As they have quite similar polarity, the bioactive compounds extracted in these solvents are very similar, therefore the detected differences between the methanol and ethanol extracts were only quantitatively ones. The main reason for this concept was that usually, the methanol extract is obtained for the purpose of phytochemical analysis, in laboratory, thus a rapid and simple extraction method is useful for the characterization of vegetal products $\left(30 \mathrm{~min}\right.$ at $\left.60^{\circ} \mathrm{C}\right)$, whereas the extract used in phytotherapy 
is generally the ethanol one, obtained by maceration at room temperature (7 days by maceration). Taking this into account, we intended to compare the results obtained by the two methods in order to evaluate if the theoretical method (with methanol) will extract the same compounds and in similar concentration and if those results could be extrapolated into practice, to ensure a more practical approach of our study.

Ajuga species contain a broad spectrum of phenolic compounds and many studies pointed out that these compounds may enhance the antioxidant activity of extracts. A comparation between the total phenolic, flavonoid and iridoid contents (TPC, TFC and TIC) of Ajuga genevensis (Ag1, Ag2, Ag3) and A. reptans (Ar1, Ar2, Ar3) different extracts (EE, ME) are presented in Table 1. The highest concentration of phenolics was obtained for the earliest collected samples of $A$. genevensis $(22.59 \pm 0.75 \mathrm{mg}$ GAE$/ \mathrm{g} \mathrm{dw}$ in methanol extract and $26.78 \pm 0.84 \mathrm{mg} \mathrm{GAE} / \mathrm{g} \mathrm{dw}$, in ethanol extract). Interestingly, for both species and for both extracts, the TPC values decreased to the lowest concentration in the next month $(A g 2$, Ar2) and afterwards, the TPC values increased again $(A g 3, A r 3)$. The variation in phenolic amounts could also be due to the status of different secondary metabolites in different growing locations, to genetic factors or ecological ones, as shown previously [24,25]. The obtained results regarding TPC values of $A$. reptans are comparable with the ones provided [23]: the methanol and ethanol flower extracts contain an amount of $20.86 \pm 0.53,24.11 \pm 0.57 \mathrm{mg}$ GAE/g respectively. Another research evaluating the chemical composition of aerial parts from Ajuga chamaecistus subsp. scoparia Rech.f. found $20.32 \pm 0.39 \mathrm{mg} \mathrm{GAE} / \mathrm{g}$ (meaning $2.64 \mathrm{mg} \mathrm{GAE} / \mathrm{g} \mathrm{dw}$ ), which is lower than the Ajuga species considered herein [20].

Table 1. Total phenolic content (TPC), total flavonoid content (TFC) and total iridoid content (TIC) in A. genevensis (Ag1, Ag2, Ag3) and A. reptans (Ar1, Ar2, Ar3) extracts ( $\pm \mathrm{SD})$.

\begin{tabular}{ccccccc}
\hline & \multicolumn{2}{c}{ TPC } & \multicolumn{2}{c}{$\begin{array}{c}\text { TFC } \\
\text { (mg RE/g dw) }\end{array}$} & \multicolumn{2}{c}{ TIC } \\
(mg AE/g dw)
\end{tabular}

Note: Values are expressed as the mean $\pm \mathrm{SD}(\mathrm{n}=3)$. ME-methanol extract, EE-ethanol extract.

A comparable trend was detected for the total flavonoid content (TFC) for ethanol and methanol extracts of evaluated Ajuga species. The highest values were obtained for Ajuga sp. harvested in the first stage of sample collection (Ag1) (15.91 \pm 0.78 and $18.72 \pm 0.85 \mathrm{mg} \mathrm{RE} / \mathrm{g} \mathrm{dw})$. These values are slightly lower than the ones presented by Jakovljević et al., 2015 for the methanol, acetone and ethyl acetate extracts from Ajuga chamaepitys (L.) Schreb $(61.77 \pm 0.51,63.87 \pm 0.66$ and $91.76 \pm 0.81 \mathrm{mg} \mathrm{RE} / \mathrm{g}$, respectively). In a previous study, the total flavonoid content for the flowers of $A$. reptans methanol extract was evaluated. The results were $12.38 \pm 0.22 \mathrm{mg} \mathrm{RE} / \mathrm{g} \mathrm{dw}$ [23], which is in accordance with the current results $(11.26 \pm 0.58$ and $14.05 \pm 0.41 \mathrm{mg} \mathrm{RE} / \mathrm{g} \mathrm{dw})$. A recent study performed by Rani et al. (2017) revealed a TFC value of $9.3 \mathrm{mg}$ QE/g dw for Ajuga bracteosa [26].

Considering the total iridoid content of various Ajuga species, there is limited accessible information. Precedent study [23] showed that Ajuga reptans ethanol extract from flowers contains iridoids in higher concentration, compared to the values presented herein $(27.49 \pm 0.94 \mathrm{vs} .21 .03 \pm 0.99 \mathrm{mg} \mathrm{AE} / \mathrm{g} \mathrm{dw})$. This could be explained by the differences regarding active compounds from vegetal material, as several research observed higher bioactive compounds content in leaf extract than stem extracts [27-29]. Interestingly, higher TIC values were obtained for A. reptans than for A. genevesis methanol and ethanol extracts. Iridoids are known as active compounds with important biological activities. They could provide protection against various chemical, physical or biological stressors. Nonetheless, these 
compounds could provide a normalizing effect without affecting the physiologically functioning systems of human body [30].

\subsection{Qualitative and Quantitative Analysis of Polyphenols}

In order to analyse the phenolic compounds from Ajuga genevensis (Ag1) and A. reptans (Ar1) extracts, an improved HPLC/UV/MS method was employed, using 18 polyphenolic compounds as standards. The aerial parts extracts from the two selected Ajuga species contain hyperoside, isoquercitrin, rutin and quercitrin (flavonoid glycosides), caffeic, $p$-coumaric and ferulic acids (phenolcarboxylic acids), apigenin and luteolin (free aglycones).

Table 2 summarizes the content in polyphenols in Ajuga genevensis and A. reptans extracts, expressed as $\mu \mathrm{g} / \mathrm{g} \mathrm{dw}$.

Table 2. The content in polyphenolic compounds from A. genevensis (Ag1) and A. reptans (Ar1) extracts by HPLC $(\mu \mathrm{g} / \mathrm{g} d w)$.

\begin{tabular}{|c|c|c|c|c|c|c|c|}
\hline $\begin{array}{l}\text { Polyphenolic } \\
\text { Compound }\end{array}$ & $\begin{array}{c}m / z \\
\text { Value }\end{array}$ & Main Daughter Ions & $\underset{(\min )}{\mathrm{R}_{\mathrm{T}} \pm \mathrm{SD}}$ & $\begin{array}{l}\text { A. genevensis } \\
\mathrm{EE}(\mu \mathrm{g} / \mathrm{g} \text { dw) }\end{array}$ & $\begin{array}{l}\text { A. genevensis } \\
\mathrm{ME}(\mu \mathrm{g} / \mathrm{g} d w)\end{array}$ & $\begin{array}{c}\text { A. reptans } \\
\mathrm{EE}(\mu \mathrm{g} / \mathrm{g} \mathrm{dw})\end{array}$ & $\begin{array}{c}\text { A. reptans } \\
\mathrm{ME}(\mu \mathrm{g} / \mathrm{g} \mathrm{dw})\end{array}$ \\
\hline Caffeic acid & 179 & 134.7 & $5.52 \pm 0.09$ & $27.88 \pm 1.17$ & $23.11 \pm 1.03$ & - & - \\
\hline$p$-Coumaric acid & 163 & 118.7 & $8.7 \pm 0.08$ & $26.21 \pm 1.26$ & $18.94 \pm 1.4$ & $30.52 \pm 2.29$ & $27.81 \pm 2.15$ \\
\hline Ferulic acid & 193 & $133.7,148.7,177.6$ & $12.0 \pm 0.10$ & $18.13 \pm 0.17$ & $18.09 \pm 0.25$ & $55.73 \pm 2.37$ & $34.74 \pm 2.28$ \\
\hline Hyperoside & 463 & $254.9,270.9,300.7$ & $19.02 \pm 0.12$ & $6.11 \pm 0.08$ & $5.42 \pm 0.13$ & - & - \\
\hline Isoquercitrin & 463 & $254.9,270.9,300.7,342.8$ & $19.35 \pm 0.10$ & - & - & $180.77 \pm 2.84$ & $151.1 \pm 2.77$ \\
\hline Rutin & 609 & $254.9,270.9,300.7,342.8$ & $20.06 \pm 0.15$ & - & - & $9.67 \pm 0.51$ & $7.35 \pm 0.46$ \\
\hline Quercitrin & 447 & $178.8,300.7$ & $23.44 \pm 0.13$ & $15.49 \pm 0.14$ & $11.13 \pm 0.11$ & $5.92 \pm 0.43$ & $3.46 \pm 0.29$ \\
\hline Luteolin & 285 & $150.6,174.6,198.6,240.7$ & $29.64 \pm 0.19$ & $46.16 \pm 1.93$ & $42.97 \pm 1.89$ & $29.27 \pm 0.77$ & $28.44 \pm 0.68$ \\
\hline Apigenin & 269 & $148.6,150.6,224.7,226.7$ & $33.10 \pm 0.17$ & $28.73 \pm 1.65$ & $25.39 \pm 1.38$ & $38.31 \pm 2.28$ & $31.89 \pm 2.13$ \\
\hline
\end{tabular}

Note: Values are the mean \pm SD $(n=3)$. ME-methanol extract, EE-ethanol extract, - Not found or below limit of detection.

Isoquercitrin-known as quercetin-3-glucoside-was the main polyphenol from $A$. reptans extracts $(180.77 \pm 2.84$ and $151.1 \pm 2.77 \mu \mathrm{g} / \mathrm{g} \mathrm{dw}$, respectively). The positive biological activity of isoquercitrin was assessed in vitro and in vivo, this compound being known to exert chemoprotective activities against allergic reactions, oxidative stress, diabetes, cardiovascular disorders and cancer. Current research on isoquercitrin indicates that it is more water-soluble and bioavailable than its aglycone. After oral administration, isoquercitrin can be detected unmodified in plasma and tissues [31]. Interestingly, the compound was not found in A. genevensis extracts at all. Five polyphenolic compounds were identified in all extracts ( $p$-coumaric, ferulic acids, quercitrin, luteolin and apigenin), two phenolcarboxylic acids only in A. genevensis extracts, whilst two flavonoid glycosides only in A. reptans extracts. The pattern of polyphenols could be employed as potential taxonomic markers due to the fact that important differences between the two Ajuga species were observed.

\subsection{Qualitative and Quantitative Analysis of Phytosterolic Compounds}

Concentrations of phytosterols in the Ajuga genevensis (Ag1) and A. reptans (Ar1) extracts (EE, PEE, CE) are presented in Table 3. Due to the fact that three compounds (ergosterol, stigmasterol, brassicasterol) were found in very small amount (below the limit of quantification), they were only identified in all extracts. Significant differences between the analysed Ajuga genevensis extracts were observed: campesterol was identified in PEE and CE, with higher amounts in the latter. A. reptans CE was richer in phytosterols and the main compound was $\beta$-sitosterol (10923.02 $\pm 18.65 \mu \mathrm{g} / \mathrm{mL})$, while a significant smaller content was determined in EE $(2048.28 \pm 9.31 \mu \mathrm{g} / \mathrm{mL})$. The results can be correlated with previous studies regarding the two analysed Ajuga species. Stigmasterol and $\beta$-sitosterol were identified by TLC in both Ajuga species extracts by Ghita et al. (2011) [32]. Ajuga relicta, A. bracteosa and $A$. taiwanensis extracts contain these compounds, stating once more that those compounds are common in Ajuga genus [17]. 
Table 3. The content in sterols in A. genevensis (Ag1) and A. reptans (Ar1) extracts ( $\mu \mathrm{g} / \mathrm{mL}$ extract).

\begin{tabular}{ccc}
\hline Extract & $\beta$-Sitosterol & Campesterol \\
\hline Ag1 EE & - & - \\
Ag1 PEE & - & $321.0 \pm 4.39$ \\
Ag1 CE & - & $832.6 \pm 5.23$ \\
Ar1 EE & $2048.28 \pm 9.31$ & - \\
Ar1 PEE & - & $511.35 \pm 4.48$ \\
Ar1 CE & $10923.02 \pm 18.65$ & $1446.44 \pm 8.92$ \\
\hline
\end{tabular}

Note: Values are the mean $\pm \mathrm{SD}(\mathrm{n}=3)$. EE-ethanol extract, $\mathrm{PEE}$ - petroleum ether extract, $\mathrm{CE}$-chloroform extract, - Not found, below the limit of detection.

\subsection{Qualitative and Quantitative Analysis of Iridoids}

The iridoids are considered chemotaxonomical markers in Ajuga species and various studies identified iridoid glycosides such as harpagide in several Ajuga plants [33,34]. Previous research demonstrated the anti-inflammatory, diuretic, antipyretic and astringent properties of some Ajuga species correlated with the presence of iridoids [12,35,36].

In the present study, the HPLC-MS/MS analysis of iridoids from $A$. genevensis ( $A g 1, A g 2, A g 3$ ) and $A$. reptans $(A r 1, A r 2, A r 3$ ) aerial parts extracts was performed. From the obtained results (Table 4), it might be noticed that the major compound identified in all extracts was 8-O-acetylharpagide (481.2 $\pm 5.76,470.6 \pm 5.44$ and $462.5 \pm 5.23 \mu \mathrm{g} / \mathrm{mL}$ in $A g 1, A g 2$ and $A g 3$ ethanol extracts, respectively), followed by harpagide $(199.7 \pm 4.92,186.4 \pm 3.71$ and $180.7 \pm 3.5 \mu \mathrm{g} / \mathrm{mL}$ in $A g 1, A g 2$ and $A g 3$ ethanol extracts), while the aucubin and catalpol were found in lower amounts. The important content in iridoids could be directly connected with their pharmaceutical effectiveness. In all analysed samples, we observed that ethanol extracts contain higher amounts of iridoids than methanol extracts and that is in accordance with preceding research [12]. Several iridoids (namely ajugoside, reptoside, 8-O-acetylharpagide, harpagide) which are known as markers for various Lamiaceae species were isolated from A. chamaepitys aerial parts from Italy in a former study [13]. The determination of iridoids in A. genevensis and A. reptans extracts using the simple, rapid and accurate HPLC-MS/MS method allowed the standardization of these extracts. The HPLC analysis revealed that $A$. reptans aerial parts contain the highest amount of iridoids and the spectrophotometric determinations showed the same tendency. The high content in iridoid glycosides could explain the antifungal and anti-inflammatory effects of Ajuga sp. extracts, in accordance with previous studies [12,36,37].

The phytochemical evaluation of the six samples collected in different harvesting time and locations showed that the aerial parts of A. genevensis and A. reptans harvested in April from Cluj County contain the highest number of polyphenolic compounds and iridoids, respectively.

The obtained results allow the characterization of A. genevensis and A. reptans aerial parts extracts in main biologically active compounds, therefore the possibility of correlation between the therapeutic effect and the effective dose.

Table 4. The quantification of iridoids in in A. genevensis (Ag1, Ag2, Ag3) and A. reptans (Ar1, Ar2, Ar3) extracts $(\mu \mathrm{g} / \mathrm{mL}$ extract).

\begin{tabular}{cccccc}
\hline Extract & Harpagide & Aucubin & Catalpol & Harpagoside & 8-O-acetyl-harpagide \\
\hline Ag1 EE & $199.7 \pm 4.92$ & $8.2 \pm 0.73$ & $12.4 \pm 1.68$ & $1.2 \pm 0.1$ & $481.2 \pm 5.76$ \\
Ag1 ME & $193.6 \pm 4.8$ & $7.9 \pm 0.68$ & $11.7 \pm 1.47$ & $1.1 \pm 0.09$ & $475.3 \pm 5.61$ \\
Ag2 EE & $186.4 \pm 3.71$ & $6.1 \pm 0.61$ & $10.8 \pm 1.36$ & $0.9 \pm 0.08$ & $470.6 \pm 5.44$ \\
Ag2 ME & $182.5 \pm 3.69$ & $5.8 \pm 0.47$ & $10.1 \pm 1.22$ & $0.7 \pm 0.05$ & $461.9 \pm 5.17$ \\
Ag3 EE & $180.7 \pm 3.5$ & $5.4 \pm 0.42$ & $9.1 \pm 0.85$ & $0.8 \pm 0.07$ & $462.5 \pm 5.23$ \\
Ag3 ME & $177.3 \pm 3.41$ & $5.2 \pm 0.39$ & $8.8 \pm 0.81$ & $0.7 \pm 0.04$ & $460.7 \pm 5.08$ \\
Ar1 EE & $267.5 \pm 5.74$ & $20.7 \pm 2.32$ & $12.6 \pm 1.51$ & $0.8 \pm 0.06$ & $543.7 \pm 8.61$ \\
Ar1 ME & $260.2 \pm 5.56$ & $18.3 \pm 2.2$ & $11.7 \pm 1.48$ & $0.7 \pm 0.06$ & $540.8 \pm 7.95$ \\
\hline
\end{tabular}


Table 4. Cont.

\begin{tabular}{cccccc}
\hline Extract & Harpagide & Aucubin & Catalpol & Harpagoside & 8-O-acetyl-harpagide \\
\hline Ar2 EE & $250.8 \pm 5.48$ & $18.4 \pm 2.18$ & $11.2 \pm 1.44$ & $0.5 \pm 0.04$ & $495.6 \pm 7.53$ \\
Ar2 ME & $248.1 \pm 5.03$ & $16.1 \pm 1.97$ & $10.3 \pm 1.37$ & $0.4 \pm 0.03$ & $492.7 \pm 7.32$ \\
Ar3 EE & $244.6 \pm 4.98$ & $15.9 \pm 1.85$ & $10.0 \pm 1.32$ & $0.4 \pm 0.02$ & $481.9 \pm 7.07$ \\
Ar3 ME & $240.3 \pm 4.7$ & $14.8 \pm 1.82$ & $9.8 \pm 0.88$ & $0.2 \pm 0.01$ & $476.5 \pm 6.89$ \\
\hline \multicolumn{7}{r}{ Note: ME-methanol extract, EE—ethanol extract. Values are the mean + SD $(\mathrm{n}=3)}$.
\end{tabular}

\subsection{The Evaluation of Antioxidant Activity}

2.5.1. DPPH (2,2-diphenyl-1-picrylhydrazyl) assay and ABTS (2,2'-azinobis-(3-ethylbenzothiazoline-6-sulfonic acid)) Radical Scavenging Activity

Considering the presented results for phytochemical characterization of A. genevensis (Ag1, Ag2, $A g 3$ ) and $A$. reptans ( $A r 1, A r 2, A r 3$ ) aerial parts, the evaluation of bioactivities was performed on the plant materials with higher content in active compounds. Therefore, the antioxidant activity of A. genevensis (Ag1) and A. reptans (Ar1) was evaluated for methanol and ethanol extracts, the results being summarized in Table 5 (TEAC-Trolox equivalent antioxidant capacity, EPR-electron paramagnetic resonance spectroscopy). The best DPPH IC 50 values were obtained for $A$. genevensis methanol and ethanol extracts: $33.74 \pm 1.99$ and $31.29 \pm 1.92 \mu \mathrm{g} / \mathrm{mL}$, which is considered a high antioxidant effect with an $\mathrm{IC}_{50} \leq 50 \mu \mathrm{g} / \mathrm{mL}$ [38]. Compared with other studies, all extracts exerted a higher antiradical activity. Another study documented the antioxidant effect for $A$. turkestanica roots extract $(57.84 \pm 4.19 \mu \mathrm{g} / \mathrm{mL})$ [33], while another study concerning Ajuga reptans reported a bigger amount $(65.7 \pm 3.82 \mu \mathrm{g} / \mathrm{mL})$ [21]. A previous study focused on the methanol and ethanol flower extract of A. genevensis showed $\mathrm{IC}_{50}$ values of $72.08 \pm 6.02$ and $45.45 \pm 3.27 \mu \mathrm{g} / \mathrm{mL}$, respectively [22].

Table 5. DPPH, TEAC, EPR activity of $A$. genevensis (Ag1) and A. reptans (Ar1) (mean $\pm \mathrm{SD})$.

\begin{tabular}{|c|c|c|c|c|c|}
\hline Sample & $\begin{array}{l}\text { DPPH IC } 50 \\
(\mu \mathrm{g} / \mathrm{mL}) \mathrm{EE}\end{array}$ & $\begin{array}{l}\text { DPPH IC }_{50} \\
(\mu \mathrm{g} / \mathrm{mL}) \mathrm{ME}\end{array}$ & $\begin{array}{c}\text { TEAC } \\
\mathrm{mg} \mathrm{TE} / \mathrm{g} \mathrm{dw}\end{array}$ & $\begin{array}{c}\text { EPR } \\
\mathrm{mg} \mathrm{FS} / 25 \mu \mathrm{L}\end{array}$ & $\begin{array}{c}\text { EPR } \\
\mathrm{mg} \mathrm{FS} / \mathrm{g} d w\end{array}$ \\
\hline Ag1 & $31.29 \pm 1.92$ & $33.74 \pm 1.99$ & $66.13 \pm 2.87$ & $0.253 \pm 0.02$ & $94.915 \pm 5.24$ \\
\hline Ar1 & $42.75 \pm 2.04$ & $45.68 \pm 2.34$ & $60.98 \pm 1.52$ & $0.237 \pm 0.01$ & $88.896 \pm 4.01$ \\
\hline Trolox & $11.2 \pm 0.21$ & & & & \\
\hline
\end{tabular}

ABTS is a free radical which is currently employed for the assessment of antioxidant effects. Considering the TEAC method, the values of antioxidant activities for Ajuga genevensis (Ag1) and A. reptans (Ar1) ethanol extracts were $66.13 \pm 2.87$ and $60.98 \pm 1.52 \mathrm{mg}$ TE/g extract (presented in Table 5), lower than for the previous studied Ajuga laxmannii species (71.07 $\pm 2.40 \mathrm{mg}$ TE/g extract) [12]. The high antioxidant capacity of Ajuga genevensis and A. reptans could be correlated with the content in polyphenolic compounds, found in higher concentration in A. genevensis aerial parts extracts.

\subsubsection{Electron Paramagnetic Resonance Spectroscopy (EPR)}

In order to correlate the results obtained with the ones from TEAC method, the A. genevensis (Ag1) and A. reptans (Ar1) ethanol extracts were further analysed by EPR method. Potassium nitrosodisulfonate (Fremy's salt, FS) was used as a stable radical. The method quantified the degradation of the stable radical in the presence of antioxidants from the Ajuga species extracts. After $30 \mathrm{~min}$, an amount of $94.915 \pm 5.24$ and $88.896 \pm 4.01 \mathrm{mg}$ FS/g extract was determined for Ajuga genevensis and A. reptans, respectively (Table 5). The degradation of the salt is $\sim 80 \%$ for both extracts after $5 \mathrm{~min}$ of incubation, with a slightly higher value for $A$. reptans. Moreover, the time interval from 5 to $30 \mathrm{~min}$, the degradation of Fremy's salt is quite constant and after the interval considered, the value is $\sim 70 \%$. Figure 1 summarizes the Fremy's salt's kinetic degradation. 
The EPR is a properly described, common, recognized method for the evaluation of the free radicals kinetic degradation. In a previous study regarding $A$. laxmannii extracts, the EPR value was slightly higher, of $98.073 \pm 1.23 \mathrm{mg}$ FS/g dw [12].

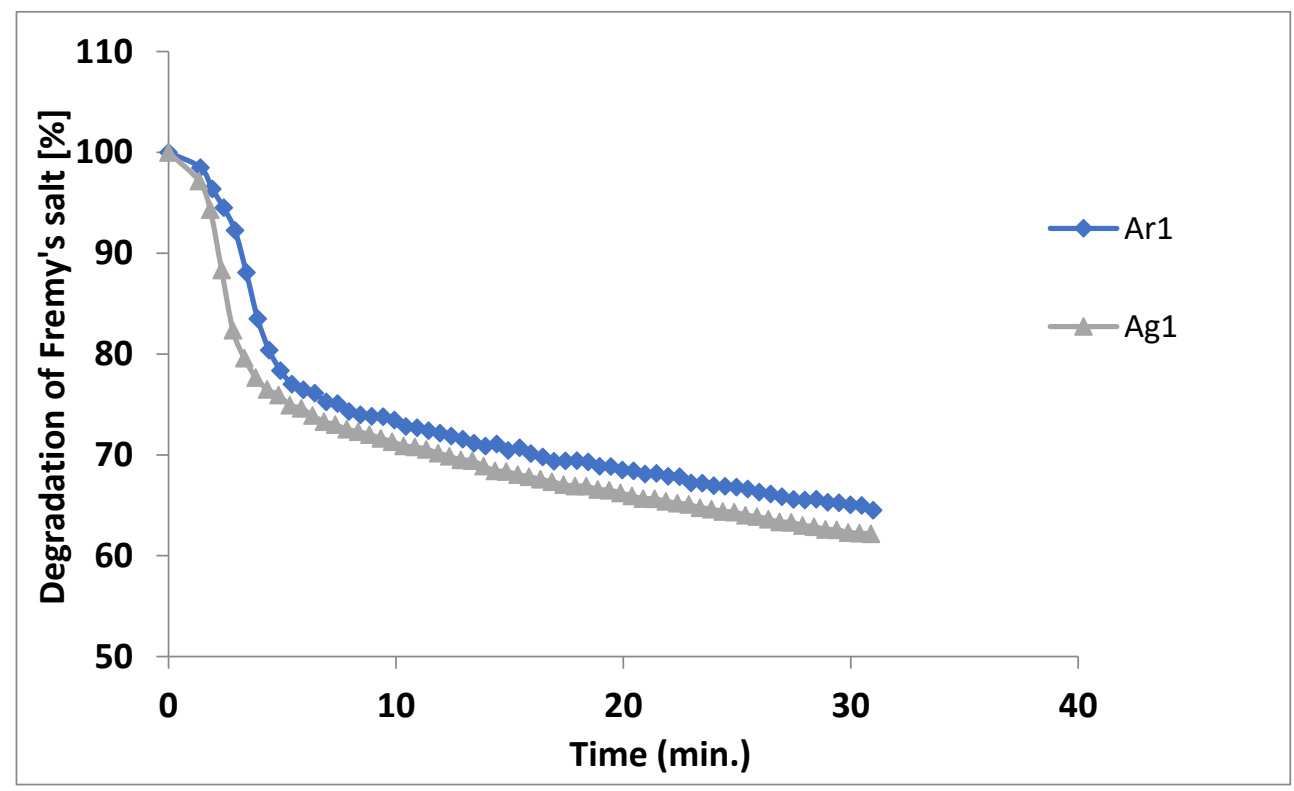

Figure 1. EPR measurements: Ag1-A. genevensis extract, Ar1-A. reptans extract.

\subsection{The Evaluation of Antibacterial Activity}

Different Gram - and Gram+ bacteria strains were employed for estimation of Ajuga species extracts antibacterial effects. The antimicrobial activity was determined using gentamycin as standard, by microdilution assay. Minimum Inhibitory Concentration (MIC) and Minimum Bactericidal Concentration (MBC) were calculated and expressed as $\mathrm{mg}$ extract $/ \mathrm{mL}$.

The values of MIC obtained for the Ajuga genevensis were between 0.78-6.25 mg/mL for EE and 1.56-6.25 mg/mL for ME (Table 6). Regarding the Ajuga reptans extracts, the MIC values were comparable with those obtained for $A$. genevensis extracts, the only notable difference being assessed for ethanol extract, with values from 0.78 to $3.12 \mathrm{mg} / \mathrm{mL}$. All extracts showed comparable activities against four bacterial strains: Escherichia coli, Listeria monocytogenes, Pseudomonas aeruginosa and Salmonella typhimurium. Ajuga genevensis and A. reptans ethanol extracts exerted the best antimicrobial activity against $S$. aureus with $\mathrm{MIC}=0.78 \mathrm{mg} / \mathrm{mL}, \mathrm{MBC}=1.56 \mathrm{mg} / \mathrm{mL}$ for both species. Escherichia coli, Salmonella typhimurium and Listeria monocytogenes were the less susceptible strains for methanol extracts obtained from both species, with a MBC value of $12.5 \mathrm{mg} / \mathrm{mL}$. A previous study [23] showed a comparable tendency for Ajuga reptans flower extracts. Good antibacterial effects can be correlated with MIC values around or less $0.5 \mathrm{mg} / \mathrm{mL}$ [39]. Therefore, modest antibacterial effects for Ajuga genevensis and A. reptans aerial parts extracts were determined.

In general, the ethanol extracts of Ajuga species exerted the highest activity against the bacterial strains tested. Some conclusions can be drawn taking into account the HPLC-MS results presented herein, concerning the antibacterial capacity of Ajuga sp. extracts. The ethanol extracts contain higher amounts of polyphenols than the methanol ones. Recently, many studies have focused on the potential of the phenolic compounds to exert antibacterial activity $[40,41]$. The presence of phenolics in ethanol extracts could determine the antimicrobial capacity exerted by Ajuga species. 
Table 6. Antibacterial activity of $A$. genevensis (Ag1) and A. reptans (Ar1) extracts.

\begin{tabular}{|c|c|c|c|c|c|c|c|c|c|c|}
\hline \multirow[t]{2}{*}{ Bacterial Strains } & \multicolumn{2}{|c|}{$\begin{array}{l}\mathrm{MIC} A g 1 \\
(\mathrm{mg} / \mathrm{mL})\end{array}$} & \multicolumn{2}{|c|}{$\begin{array}{c}\text { MBC Ag1 } \\
(\mathrm{mg} / \mathrm{mL})\end{array}$} & \multicolumn{2}{|c|}{$\begin{array}{l}\text { MIC Ar1 } \\
(\mathrm{mg} / \mathrm{mL})\end{array}$} & \multicolumn{2}{|c|}{$\begin{array}{c}\text { MBC Ar1 } \\
(\mathrm{mg} / \mathrm{mL})\end{array}$} & \multicolumn{2}{|c|}{ Gentamycin $(\mu \mathrm{g} / \mathrm{mL})$} \\
\hline & ME & EE & ME & EE & ME & $\mathrm{EE}$ & ME & EE & MIC & MBC \\
\hline S. aureus & $1.56 \pm 0.01$ & $0.78 \pm 0.01$ & $3.12 \pm 0.03$ & $1.56 \pm 0.02$ & $1.56 \pm 0.01$ & $0.78 \pm 0.01$ & $3.1 \pm 0.02$ & $1.56 \pm 0.02$ & $0.038 \pm 0.001$ & $0.076 \pm 0.002$ \\
\hline P. aeruginosa & $3.12 \pm 0.03$ & $1.56 \pm 0.02$ & $6.25 \pm 0.06$ & $3.12 \pm 0.04$ & $3.12 \pm 0.02$ & $1.56 \pm 0.01$ & $6.25 \pm 0.07$ & $3.12 \pm 0.02$ & $1.2 \pm 0.02$ & $2.4 \pm 0.04$ \\
\hline L. monocytogenes & $6.25 \pm 0.08$ & $6.25 \pm 0.07$ & $12.5 \pm 0.09$ & $12.5 \pm 0.09$ & $6.25 \pm 0.08$ & $3.12 \pm 0.03$ & $12.5 \pm 0.09$ & $6.25 \pm 0.07$ & $0.076 \pm 0.001$ & $0.15 \pm 0.01$ \\
\hline E. coli & $6.25 \pm 0.07$ & $3.12 \pm 0.03$ & $12.5 \pm 0.07$ & $6.25 \pm 0.08$ & $6.25 \pm 0.07$ & $3.12 \pm 0.04$ & $12.5 \pm 0.08$ & $6.25 \pm 0.06$ & $1.2 \pm 0.01$ & $2.4 \pm 0.05$ \\
\hline S. typhimurium & $6.25 \pm 0.09$ & $6.25 \pm 0.08$ & $12.5 \pm 0.09$ & $12.5 \pm 0.09$ & $6.25 \pm 0.08$ & $3.12 \pm 0.03$ & $12.5 \pm 0.09$ & $6.25 \pm 0.08$ & $2.4 \pm 0.03$ & $4.8 \pm 0.07$ \\
\hline
\end{tabular}

\subsection{The evaluation of Antifungal Activity}

The extracts (EE, PEE, CE) of Ajuga genevensis (Ag1) and A. reptans (Ar1) were tested for their antifungal activity by using five different species of fungi, which were selected based on the importance in public health. The evidence of antifungal properties exerted by the extracts from Ajuga genevensis (Ag1), A. reptans (Ar1) used against tested strains is summarized in Table 7 . The best susceptibility to the Ajuga reptans petroleum ether extract was shown by Candida albicans $(0.006 \mathrm{mg} / \mathrm{mL}$ and $0.012 \mathrm{mg} / \mathrm{mL}$ for minimum inhibitory concentration (MIC) and minimum fungicidal concentration (MFC). From the same Ajuga species, following highest sensitivity was shown to chloroform and ethanol extracts, with MFC $=0.025 \mathrm{mg} / \mathrm{mL}$ and MIC $=0.012 \mathrm{mg} / \mathrm{mL}$, respectively and the most resistant strains against ethanol extract of Ajuga genevensis being Penicillium fumiculosum and Aspergillus niger (MFC $0.2 \mathrm{mg} / \mathrm{mL}$ ). In their article, Kawamura and Ohara, (2005) stated that high level of iridoids contained within the plant extracts might be linked to the antifungal activity of these extracts. All extracts of aerial parts from Ajuga species showed high concentrations of iridoid glycosides, mainly 8-O-acetylharpagide. This outcome is in conformity with studies that were performed previously [12], where the antifungal activity of Ajuga laxmannii aerial parts was determined. 
Table 7. Antifungal activity of A. genevensis (Ag1) and A. reptans (Ar1) extracts.

\begin{tabular}{|c|c|c|c|c|c|c|c|c|c|c|c|c|c|c|}
\hline \multirow[t]{2}{*}{ Bacterial Strains } & \multicolumn{3}{|c|}{$\begin{array}{l}\text { MIC Ag1 } \\
(\mathrm{mg} / \mathrm{mL})\end{array}$} & \multicolumn{3}{|c|}{$\begin{array}{l}\mathrm{MFC} A g 1 \\
(\mathrm{mg} / \mathrm{mL})\end{array}$} & \multicolumn{3}{|c|}{$\begin{array}{l}\text { MIC Ar1 } \\
(\mathrm{mg} / \mathrm{mL})\end{array}$} & \multicolumn{3}{|c|}{$\begin{array}{l}\text { MFC Ar1 } \\
(\mathrm{mg} / \mathrm{mL})\end{array}$} & \multicolumn{2}{|c|}{ Fluconazole $(\mu \mathrm{g} / \mathrm{mL})$} \\
\hline & $\mathrm{EE}$ & PEE & $\mathrm{CE}$ & $\mathrm{EE}$ & PEE & $\mathrm{CE}$ & $\mathrm{EE}$ & PEE & $\mathrm{CE}$ & $\mathrm{EE}$ & PEE & $\mathrm{CE}$ & $\begin{array}{c}\text { MIC } \\
(\mu \mathrm{g} / \mathrm{mL})\end{array}$ & $\begin{array}{c}\text { MFC } \\
(\mu \mathrm{g} / \mathrm{mL})\end{array}$ \\
\hline Aspergillus flavus & $0.05 \pm 0.008$ & $0.012 \pm 0.003$ & $0.025 \pm 0.007$ & $0.1 \pm 0.03$ & $0.025 \pm 0.006$ & $0.05 \pm 0.008$ & $0.025 \pm 0.006$ & $0.12 \pm 0.04$ & $0.006 \pm 0.0003$ & $0.05 \pm 0.008$ & $0.25 \pm 0.04$ & $0.012 \pm 0.005$ & $0.15 \pm 0.03$ & $0.3 \pm 0.05$ \\
\hline Aspergillus niger & $0.1 \pm 0.02$ & $0.012 \pm 0.005$ & $0.012 \pm 0.004$ & $0.2 \pm 0.06$ & $0.025 \pm 0.005$ & $0.025 \pm 0.006$ & $0.05 \pm 0.008$ & $0.012 \pm 0.005$ & $0.012 \pm 0.004$ & $0.1 \pm 0.03$ & $0.025 \pm 0.005$ & $0.025 \pm 0.006$ & $0.15 \pm 0.03$ & $0.3 \pm 0.06$ \\
\hline Candida albicans & $0.025 \pm 0.006$ & $0.012 \pm 0.006$ & $0.025 \pm 0.007$ & $0.05 \pm 0.008$ & $0.025 \pm 0.005$ & $0.05 \pm 0.008$ & $0.012 \pm 0.005$ & $0.006 \pm 0.0003$ & $0.012 \pm 0.004$ & $0.025 \pm 0.006$ & $0.012 \pm 0.005$ & $0.025 \pm 0.007$ & $0.1 \pm 0.02$ & $0.2 \pm 0.04$ \\
\hline Candida parapsilosis & $0.025 \pm 0.006$ & $0.012 \pm 0.005$ & $0.05 \pm 0.009$ & $0.05 \pm 0.008$ & $0.025 \pm 0.007$ & $0.05 \pm 0.008$ & $0.025 \pm 0.007$ & $0.025 \pm 0.006$ & $0.012 \pm 0.003$ & $0.05 \pm 0.009$ & $0.05 \pm 0.008$ & $0.025 \pm 0.005$ & $0.1 \pm 0.02$ & $0.2 \pm 0.04$ \\
\hline Penicillium fumiculosum & $0.1 \pm 0.03$ & $0.05 \pm 0.008$ & $0.025 \pm 0.006$ & $0.2 \pm 0.05$ & $0.1 \pm 0.03$ & $0.05 \pm 0.009$ & $0.05 \pm 0.008$ & $0.05 \pm 0.007$ & $0.05 \pm 0.008$ & $0.1 \pm 0.02$ & $0.1 \pm 0.03$ & $0.1 \pm 0.02$ & $0.15 \pm 0.03$ & $0.3 \pm 0.06$ \\
\hline
\end{tabular}

Note: PEE—petroleum ether extract, EE—ethanol extract, $\mathrm{CE}$-chloroform extract. 


\subsection{The Evaluation of In Vivo Anti-Inflammatory Activity}

Three Ajuga genevensis (Ag1) and A. reptans (Ar1) ethanol extracts $(25 \mathrm{mg} \mathrm{dw} / \mathrm{mL}, 50 \mathrm{mg} \mathrm{dw} / \mathrm{mL}$ and $100 \mathrm{mg} \mathrm{dw} / \mathrm{mL}$ ) were tested for their anti-inflammatory effects in vivo. The experimental rat acute inflammation was induced by a non-antigenic inflammatory stimulus. The turpentine oil activates inflammatory cytokines, reactive oxygen species (ROS) and NO release. High serum concentrations of ROS and NOx are considered as positive markers of oxidative stress in the inflammatory response. Diclofenac was used as the positive control.

Oxidative stress may be the consequence of excessive ROS formation or of the antioxidants deficiency. For ROS synthesis evaluation was used the TOS. TOS was significantly increased $(p<0.001)$ by the inflammation induced by turpentine, whereas the diclofenac administration determined the decrease of this parameter significantly $(p<0.001)$ (Figure 2A). Remarkably, the administration of Ajuga reptans extract dilutions lowered TOS. The $25 \mathrm{mg} \mathrm{dw} / \mathrm{mL}(p<0.01)$ and $100 \mathrm{mg} \mathrm{dw} / \mathrm{mL}(p<0.001)$ extracts had the best inhibitory activities. The treatment with diclofenac had a comparable effect on TOS inhibition $(p<0.01)$, in comparison with the administration of $100 \mathrm{mg} \mathrm{dw} / \mathrm{mL}(p<0.01)$ and $25 \mathrm{mg} \mathrm{dw} / \mathrm{mL}(p<0.01)$ extracts. The Ajuga reptans and A. genevensis $50 \mathrm{mg} \mathrm{dw} / \mathrm{mL}$ extracts did not influence TOS significantly $(p>0.05)$.

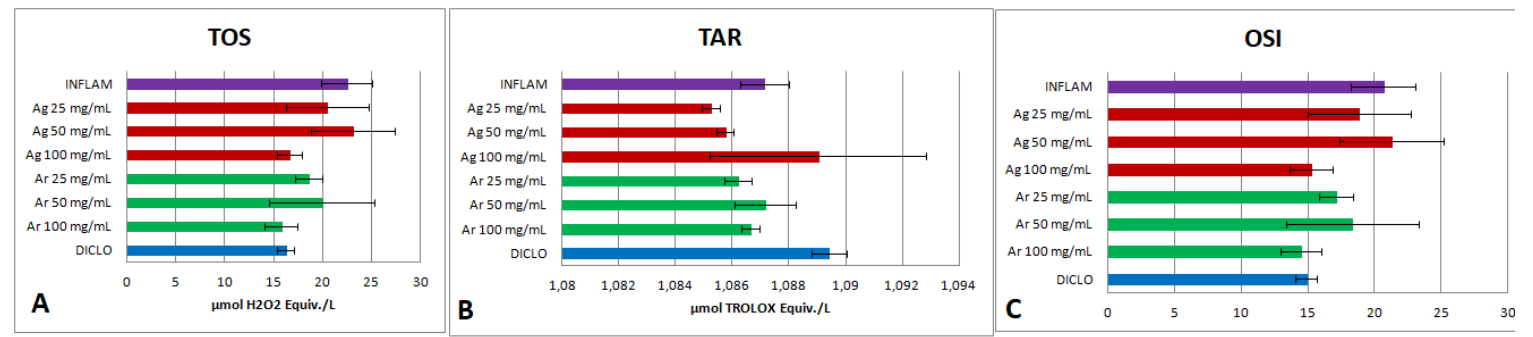

Figure 2. Oxidative stress tests. (A) Total oxidative status (TOS). (B) Total antioxidant response (TAR). (C) Oxidative stress index (OSI). Note: Diclo-animals were given $20 \mathrm{mg} / \mathrm{kg}$ BW diclofenac, Inflam-the induction of inflammation was made by intramuscular injection of turpentine oil $(6 \mathrm{~mL} / \mathrm{kg} \mathrm{BW}), A g 25 \mathrm{mg} / \mathrm{mL}$-animals were given $5 \mathrm{~mL} / \mathrm{kg}$ BW A. genevensis ethanol extract $25 \mathrm{mg} \mathrm{dw} / \mathrm{mL}, A g 50 \mathrm{mg} / \mathrm{mL}$-animals were given $5 \mathrm{~mL} / \mathrm{kg}$ BW A. genevensis ethanol extract $50 \mathrm{mg} \mathrm{dw} / \mathrm{mL}, A g 100 \mathrm{mg} / \mathrm{mL}$-animals were given $5 \mathrm{~mL} / \mathrm{kg}$ BW A. genevensis ethanol extract $100 \mathrm{mg} \mathrm{dw} / \mathrm{mL}$, Ar $25 \mathrm{mg} / \mathrm{mL}$-animals were given $5 \mathrm{~mL} / \mathrm{kg}$ BW A. reptans ethanol extract $25 \mathrm{mg}$ $\mathrm{dw} / \mathrm{mL}$, Ar $50 \mathrm{mg} / \mathrm{mL}$-animals were given $5 \mathrm{~mL} / \mathrm{kg}$ BW A. reptans ethanol extract $50 \mathrm{mg} \mathrm{dw} / \mathrm{mL}, A r$ $100 \mathrm{mg} / \mathrm{mL}$-animals were given $5 \mathrm{~mL} / \mathrm{kg}$ BW A. reptans ethanol extract $100 \mathrm{mg} \mathrm{dw} / \mathrm{mL}(p<0.001)$.

For antioxidant defence mechanism, TAR was evaluated. TAR was slightly increased by the diclofenac treatment $(p<0.05)$ and was reduced for inflammation group $(p<0.05)$ (Figure 2B). Ajuga genevensis $100 \mathrm{mg} \mathrm{dw} / \mathrm{mL}$ extract increased TAR $(p<0.01)$ and the effect was as good as that of diclofenac $(p>0.05)$.

The general evaluation of the oxidative stress was performed using the OSI. The parameter was significantly elevated in the inflammation group $(p<0.001)$, whilst a decrease of OSI was observed for diclofenac treatment $(p<0.001)$ (Figure $2 \mathrm{C}$ ). The Ajuga reptans $100 \mathrm{mg} \mathrm{dw} / \mathrm{mL}$ extract and A. genevensis $100 \mathrm{mg} \mathrm{dw} / \mathrm{mL}$ extracts induced an important reduction of OSI $(p<0.001)$, comparable with the diclofenac effect $(p<0.05)$.

ROS may react with NO generating reactive nitrogen species (RNS), which are also strong oxidants. NO synthesis was indirectly evaluated by measuring NOx. NOx was reduced in the group treated with diclofenac $(p<0.01)$, and, moreover was significantly higher in the inflammation group $(p<0.01)$ (Figure $3 \mathrm{~A})$. The $A$. reptans $100 \mathrm{mg} \mathrm{dw} / \mathrm{mL}$ extract reduced NOx significantly $(p<0.01)$, compared with the inflammation group. There was no important inhibitory activity on NOx in all A. genevensis extracts $(p>0.05)$. The OSI was correlated with NOx $(r=0.81)$ and TOS $(r=0.92)$. 


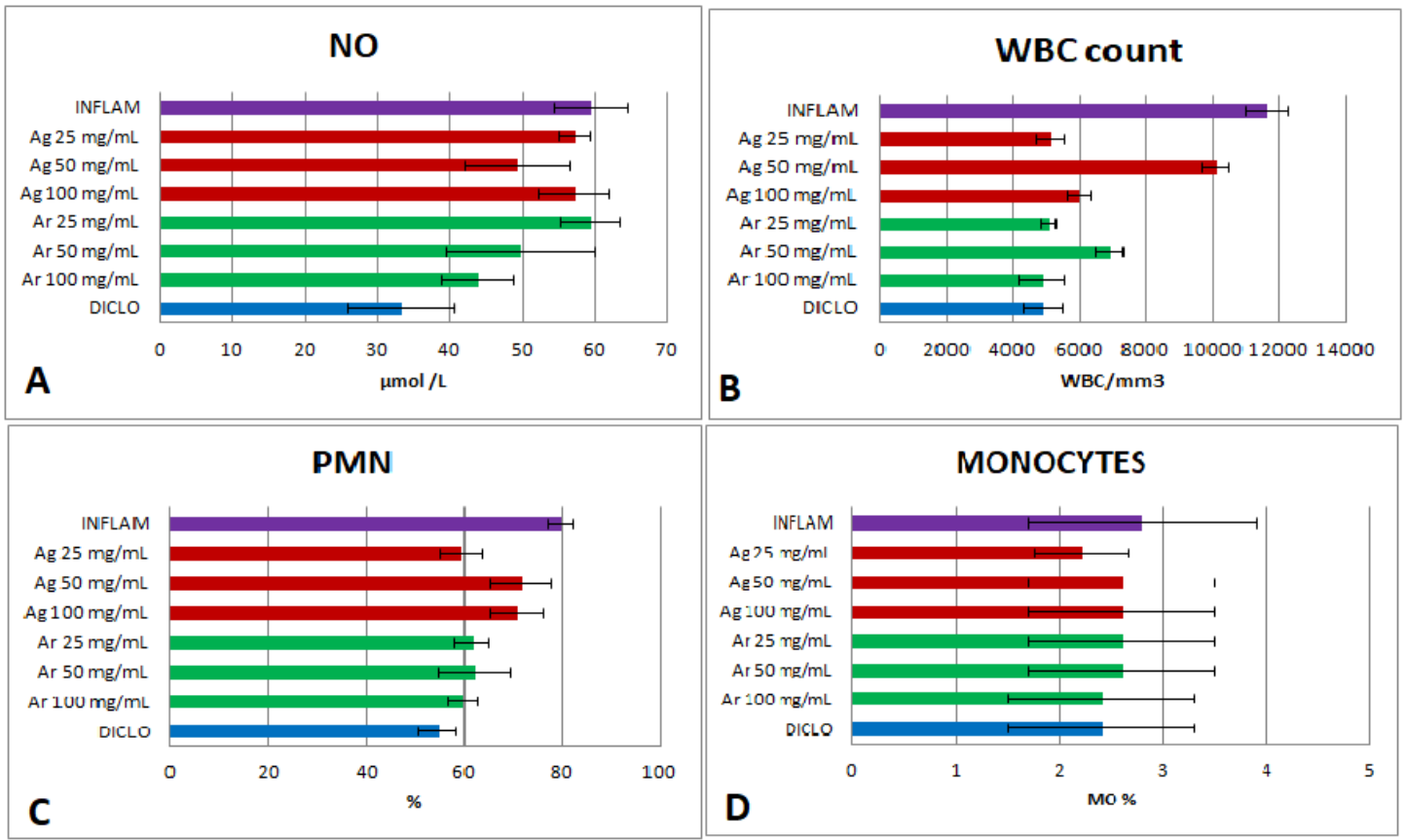

Figure 3. Anti-inflammatory effect tests. (A) NO synthesis. (B) White blood cells (WBC) count. (C) Polymorphonuclear leukocytes (PMN). (D) Total number of monocytes (MO). Note: Diclo-animals were given $20 \mathrm{mg} / \mathrm{kg}$ BW diclofenac, Inflam—the induction of inflammation was made by intramuscular injection of turpentine oil ( $6 \mathrm{~mL} / \mathrm{kg} \mathrm{BW}), A g 25 \mathrm{mg} / \mathrm{mL}$-animals were given $5 \mathrm{~mL} / \mathrm{kg}$ BW A. genevensis ethanol extract $25 \mathrm{mg} \mathrm{dw} / \mathrm{mL}, A g 50 \mathrm{mg} / \mathrm{mL}$-animals were given $5 \mathrm{~mL} / \mathrm{kg}$ BW A. genevensis ethanol extract $50 \mathrm{mg} \mathrm{dw} / \mathrm{mL}, A g 100 \mathrm{mg} / \mathrm{mL}$-animals were given $5 \mathrm{~mL} / \mathrm{kg}$ BW A. genevensis ethanol extract $100 \mathrm{mg} \mathrm{dw} / \mathrm{mL}$, Ar $25 \mathrm{mg} / \mathrm{mL}$-animals were given $5 \mathrm{~mL} / \mathrm{kg}$ BW A. reptans ethanol extract $25 \mathrm{mg} \mathrm{dw} / \mathrm{mL}$, Ar $50 \mathrm{mg} / \mathrm{mL}$-animals were given $5 \mathrm{~mL} / \mathrm{kg}$ BW A. reptans ethanol extract $50 \mathrm{mg} \mathrm{dw} / \mathrm{mL}$, Ar $100 \mathrm{mg} / \mathrm{mL}$-animals were given $5 \mathrm{~mL} / \mathrm{kg}$ BW A. reptans ethanol extract $100 \mathrm{mg} \mathrm{dw} / \mathrm{mL}(p<0.001)$.

The evaluation of anti-inflammatory properties of Ajuga species extracts was also achieved by calculating the WBC count and the differential WBC count. All Ajuga reptans extracts reduced the total WBC count in a significant manner $(p<0.001)$ compared to the inflammation group (Figure 3B) by lowering PMN \% (Figure 3C) and MO \% (Figure 3D). Ajuga reptans $25 \mathrm{mg} \mathrm{dw} / \mathrm{mL}$ and $100 \mathrm{mg} \mathrm{dw} / \mathrm{mL}$ extracts were the best inhibitors $(p<0.001)$ on the WBC and they were similar to diclofenac effects $(p>0.05)$.

Ajuga genevensis extracts reduced in a significant manner $(p<0.001)$ the total WBC count (Figure 3B) by reducing PMN \% (Figure 3C) and MO \% (Figure 3D), in comparison with the inflammation group.

Each extract dilution was then assessed for the capacity to inhibit phagocytosis in vitro. The Ajuga genevensis $25 \mathrm{mg} \mathrm{dw} / \mathrm{mL}$ and $A$. reptans $100 \mathrm{mg} \mathrm{dw} / \mathrm{mL}$ extracts exhibited the most important inhibitory activity towards phagocytosis. The effect of Ajuga reptans extract was correlated with a reduction of PA and PI (Figure 4A,B) $(p<0.001)$. Ajuga genevensis $25 \mathrm{mg} \mathrm{dw} / \mathrm{mL}$ and $100 \mathrm{mg} \mathrm{dw} / \mathrm{mL}$ extracts also determined a reduction of PI (Figure $4 \mathrm{~B})(p<0.001)$. 


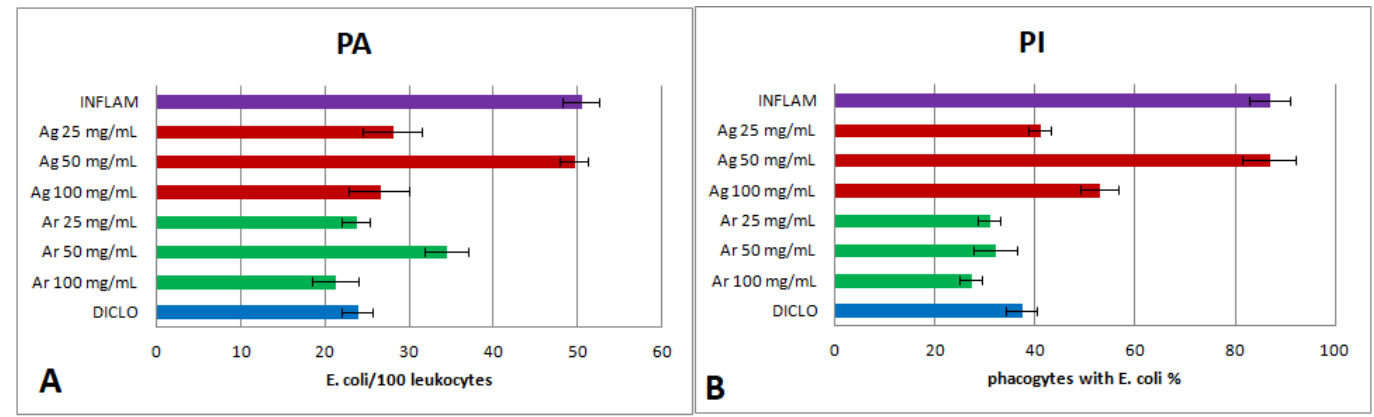

Figure 4. Phagocytosis test parameters. (A) Phagocytic activity (PA). (B) Phagocytic index (PI). Note: Diclo-animals were given $20 \mathrm{mg} / \mathrm{kg}$ BW diclofenac, Inflam — the induction of inflammation was made by intramuscular injection of turpentine oil ( $6 \mathrm{~mL} / \mathrm{kg} \mathrm{BW}), A g 25 \mathrm{mg} / \mathrm{mL}$-animals were given $5 \mathrm{~mL} / \mathrm{kg}$ BW A. genevensis ethanol extract $25 \mathrm{mg} \mathrm{dw} / \mathrm{mL}, A g 50 \mathrm{mg} / \mathrm{mL}$-animals were given $5 \mathrm{~mL} / \mathrm{kg}$ BW $A$. genevensis ethanol extract $50 \mathrm{mg} \mathrm{dw} / \mathrm{mL}, A g 100 \mathrm{mg} / \mathrm{mL}$-animals were given $5 \mathrm{~mL} / \mathrm{kg}$ BW A. genevensis ethanol extract $100 \mathrm{mg} \mathrm{dw} / \mathrm{mL}$, Ar $25 \mathrm{mg} / \mathrm{mL}$-animals were given $5 \mathrm{~mL} / \mathrm{kg}$ BW A. reptans ethanol extract $25 \mathrm{mg} \mathrm{dw} / \mathrm{mL}, \operatorname{Ar} 50 \mathrm{mg} / \mathrm{mL}$-animals were given $5 \mathrm{~mL} / \mathrm{kg}$ BW A. reptans ethanol extract $50 \mathrm{mg}$ $\mathrm{dw} / \mathrm{mL}, \operatorname{Ar} 100 \mathrm{mg} / \mathrm{mL}$-animals were given $5 \mathrm{~mL} / \mathrm{kg}$ BW A. reptans ethanol extract $100 \mathrm{mg} \mathrm{dw} / \mathrm{mL}$ $(p<0.001)$.

The presented results are in accordance with the hypothesis that extracts from Ajuga genevensis (Ag1) and $A$. reptans (Ar1) aerial parts have anti-inflammatory effects through the inhibition of phagocytosis by the reduction of oxidative stress (Table 8 ).

Table 8. Anti-inflammatory activity of $A$. genevensis (Ag1) and A. reptans (Ar1) extracts (WBC, PMN, MO, PA, PI, TAR, TOS, NO, OSI).

\begin{tabular}{|c|c|c|c|c|c|c|c|c|}
\hline Parameter & $\begin{array}{c}\mathrm{Ag} 100 \mathrm{mg} \\
\mathrm{dw} / \mathrm{mL}\end{array}$ & $\begin{array}{c}A g 50 \mathrm{mg} \\
\mathrm{dw} / \mathrm{mL}\end{array}$ & $\begin{array}{l}\mathrm{Ag} 25 \mathrm{mg} \\
\mathrm{dw} / \mathrm{mL}\end{array}$ & $\begin{array}{c}\operatorname{Ar} 100 \mathrm{mg} \\
\mathrm{dw} / \mathrm{mL}\end{array}$ & $\begin{array}{c}A r 50 \mathrm{mg} \\
\mathrm{dw} / \mathrm{mL}\end{array}$ & $\begin{array}{c}\text { Ar } 25 \mathrm{mg} \\
\mathrm{dw} / \mathrm{mL}\end{array}$ & Inflam & Diclo \\
\hline WBC & $\begin{array}{c}5953.2 \pm \\
325.22\end{array}$ & $\begin{array}{c}10077.8 \pm \\
394.84\end{array}$ & $5086.6 \pm 419.96$ & $4860 \pm 669.21$ & $6884 \pm 413.55$ & $5030 \pm 242.07$ & $11602 \pm 649.63$ & $4866.8 \pm 581.31$ \\
\hline PMN & $70.6 \pm 5.27$ & $71.4 \pm 6.06$ & $59.2 \pm 4.38$ & $59.6 \pm 2.96$ & $62 \pm 7.31$ & $61.4 \pm 3.43$ & $79.6 \pm 2.6$ & $54.4 \pm 3.84$ \\
\hline MO & $2.6 \pm 0.89$ & $2.6 \pm 0.89$ & $2.2 \pm 0.44$ & $2.4 \pm 0.89$ & $2.6 \pm 0.89$ & $2.6 \pm 0.89$ & $2.8 \pm 1.09$ & $2.4 \pm 0.89$ \\
\hline PA & $26.4 \pm 3.57$ & $49.6 \pm 1.67$ & $28 \pm 3.46$ & $21.2 \pm 2.68$ & $34.4 \pm 2.6$ & $23.6 \pm 1.67$ & $50.4 \pm 2.19$ & $23.8 \pm 1.78$ \\
\hline PI & $52.8 \pm 3.89$ & $86.8 \pm 5.4$ & $40.8 \pm 2.28$ & $27.2 \pm 2.28$ & $32 \pm 4.24$ & $30.8 \pm 2.28$ & $86.8 \pm 4.14$ & $37.2 \pm 3.03$ \\
\hline TAR & $1.0890 \pm 0.003$ & $1.0857 \pm 0.0002$ & $1.0852 \pm 0.0003$ & $1.0866 \pm 0.0003$ & $1.0871 \pm 0.001$ & $1.0862 \pm 0.0004$ & $1.0871 \pm 0.0008$ & $1.0894 \pm 0.0006$ \\
\hline TOS & $16.602 \pm 1.22$ & $23.095 \pm 4.25$ & $20.461 \pm 4.21$ & $15.767 \pm 1.66$ & $19.913 \pm 5.43$ & $18.584 \pm 1.35$ & $22.469 \pm 2.64$ & $16.208 \pm 0.85$ \\
\hline NO & $57.113 \pm 4.85$ & $49.219 \pm 7.21$ & $57.083 \pm 2.13$ & $43.770 \pm 5.03$ & $49.631 \pm 8.2$ & $59.322 \pm 4.08$ & $59.293 \pm 5.07$ & $33.231 \pm 7.35$ \\
\hline OSI & $15.247 \pm 1.61$ & $21.270 \pm 3.91$ & $18.854 \pm 3.88$ & $14.510 \pm 1.53$ & $18.314 \pm 4.97$ & $17.109 \pm 1.25$ & $20.667 \pm 2.42$ & $14.878 \pm 0.78$ \\
\hline
\end{tabular}

Note: $A g 100 \mathrm{mg} / \mathrm{mL}$-animals were given $5 \mathrm{~mL} / \mathrm{kg} \mathrm{BW} \mathrm{A.} \mathrm{genevensis} \mathrm{ethanol} \mathrm{extract} 100 \mathrm{mg} \mathrm{dw} / \mathrm{mL}, A g$ $50 \mathrm{mg} / \mathrm{mL}$-animals were given $5 \mathrm{~mL} / \mathrm{kg}$ BW A. genevensis ethanol extract $50 \mathrm{mg} \mathrm{dw} / \mathrm{mL}, A g 25 \mathrm{mg} / \mathrm{mL}$-animals were given $5 \mathrm{~mL} / \mathrm{kg} \mathrm{BW}$ A. genevensis ethanol extract $25 \mathrm{mg} \mathrm{dw} / \mathrm{mL}, \operatorname{Ar} 100 \mathrm{mg} / \mathrm{mL}$-animals were given $5 \mathrm{~mL} / \mathrm{kg} \mathrm{BW}$ A. reptans ethanol extract $100 \mathrm{mg} \mathrm{dw} / \mathrm{mL}, \operatorname{Ar} 50 \mathrm{mg} / \mathrm{mL}$-animals were given $5 \mathrm{~mL} / \mathrm{kg}$ BW A. reptans ethanol extract $50 \mathrm{mg} \mathrm{dw} / \mathrm{mL}$, Ar $25 \mathrm{mg} / \mathrm{mL}$-animals were given $5 \mathrm{~mL} / \mathrm{kg} \mathrm{BW}$ A. reptans ethanol extract $25 \mathrm{mg} \mathrm{dw} / \mathrm{mL}$, Inflam—the induction of inflammation was made by intramuscular injection of turpentine oil ( $6 \mathrm{~mL} / \mathrm{kg} \mathrm{BW})$, Diclo-animals were given $20 \mathrm{mg} / \mathrm{kg}$ BW diclofenac.

Ajuga reptans and $A$. genevensis extracts exerted a lower anti-nitro-oxidative stress and anti-inflammatory effect than treatment with diclofenac $(p<0.001)$. Ajuga reptans $100 \mathrm{mg} \mathrm{dw} / \mathrm{mL}$ extract exerted the best effect compared to diclofenac.

Previous studies suggest that some natural products may play an important anti-inflammatory role, because they inhibit NO synthesis. In the present research, only A. reptans $100 \mathrm{mg} \mathrm{dw} / \mathrm{mL}$ extract proved to have important anti-inflammatory effects by reducing NO synthesis and it was comparable with that induced by diclofenac. Because the effects on NOx were not always correlated with the in vitro antioxidant tests, it may be presumed that the antioxidant activity was not significantly involved. In some human diseases, antioxidant therapy failure was called the antioxidant paradox. Due to the fact that overproduction of ROS could determine an inflammatory response and inflammatory mediators may induce an oxidative stress, it was generally accepted that oxidation and inflammation are 
interlinked processes. The latest explanation of antioxidant therapy failure comes from the finding that antioxidants do not inhibit oxidative stress and the associated inflammation at the same time [42,43].

As our results revealed, although the two Ajuga species extracts had comparable amounts of phytochemicals and close related results for in vitro evaluation of antioxidant effects were observed, in vivo studies showed significant differences in anti-inflammatory activities of three doses of the same (ethanol) extract.

Whereas numerous in vitro and in vivo studies demonstrated the anti-inflammatory, antioxidant, neuroprotective effects of polyphenolic compounds, other research also highlighted the fact that rutin and quercetin derivatives can act as pro-oxidant molecules, depending on concentration and reaction conditions [44]. Therefore, it could be a dose dependent "double-edged sword" effect: lower doses have a moderate anti-oxidant effect, while higher doses could induce the increase of the levels of endogenous antioxidants and melanin production as an adaptive response to oxidative damage [45,46].

Consecutive, the use of ethanol extract in phytotherapy for anti-inflammatory effects requires the standardization in main active compounds in order to provide an effective herbal preparation.

\section{Materials and Methods}

\subsection{Reagents and Chemicals}

Caffeic, chlorogenic, $p$-coumaric, gallic acids, isoquercitrin, rutin, quercetin, hyperoside, fisetin, quercetol, kaempferol, apigenin, myricetol, harpagoside, catalpol, aucubin, ergosterol, $\beta$-sitosterol, stigmasterol, brassicasterol, campesterol were standards from Merck (Darmstadt, Germany), 8-O-acetyl-harpagide, harpagide from PhytoLab (Vestenbergsgreuth, Germany), caftaric acid from Dalton (Toronto, ON, Canada), gentisic, sinapic, ferulic acids, luteolin, patuletin were obtained from Roth (Karlsruhe, Germany). Copper (II) sulphate pentahydrate, sodium carbonate, sodium acetate trihydrate, anhydrous aluminium chloride from Merck (Darmstadt, Germany). Solvents used for extraction and separation were HPLC analytical-grade (methanol, ammonium acetate, acetonitrile) or analytical-grade (acetic acid, hydrochloric acid, potassium hydroxide, petroleum ether, silver nitrate, n-hexane, chloroform) and Folin-Ciocâlteu reagent were acquired from Merck (Darmstadt, Germany). Fremy's salt and horseradish peroxidase (HRP) purchased from Merck (Darmstadt, Germany), 2,2-diphenyl-1-picrylhydrazyl (DPPH) and 6-hydroxy-2,5,7,8-tetramethylchroman-2-carboxylic acid (Trolox) were from Alfa-Aesar (Karlsruhe, Germany).

\subsection{Plant Material}

Medicinal plants were harvested at full flowering stage from different areas and periods from Romanian spontaneous flora. The aerial parts of Ajuga genevensis harvested from Cluj County in April 2017 (Ag1), harvested from Alba County in May 2017 (Ag2), harvested from Neamţ County in June 2017 (Ag3), aerial parts of Ajuga reptans harvested from Cluj County in April 2017 (Ar1), harvested from Alba County in May 2017 (Ar2), harvested from Neamţ County in June 2017 (Ar3). Plants were identified and voucher samples were preserved in the Herbarium of Pharmacognosy Department, University of Medicine and Pharmacy, Cluj-Napoca.

The extraction of each sample was performed with $70 \%$ methanol, 30 minutes at $60{ }^{\circ} \mathrm{C}$ on a water-bath (methanol extract 10\%, ME) and with 70\% ethanol for 7 days by maceration (ethanol extract $10 \%$, EE) [23]. Petroleum ether extracts 10\% (PEE) and chloroform extracts 10\% (CE) were obtained and used for the evaluation of antifungal properties, as well as for the identification and quantification of phytosterols [47]. 


\subsection{Quantitative Analyses}

\subsubsection{Total Phenolics}

The determination of total phenolic content (TPC) of the extracts obtained from Ajuga genevensis (Ag1, Ag2, Ag3) and A. reptans (Ar1, Ar2, Ar3) aerial parts was carried out as reported in previous paper by Folin-Ciocâlteu method [48]. The content in total phenolics was expressed as mg gallic acid equivalents (GAEs)/g dry weight $(\mathrm{dw})$ vegetal product. The experiments were performed in triplicate.

\subsubsection{Total Flavonoids}

The estimation of total flavonoid content (TFC) of the extracts obtained from Ajuga genevensis (Ag1, Ag2, Ag3) and A. reptans (Ar1, Ar2, Ar3) aerial parts was carried out using a spectrophotometric method [47]. The flavonoids content was expressed as rutin equivalents (mg REs)/g dw vegetal product.

\subsubsection{Total Iridoids}

The assessment of total iridoid content (TIC) of the extracts obtained from Ajuga genevensis (Ag1, $A g 2, A g 3)$ and $A$. reptans $(A r 1, A r 2, A r 3)$ aerial parts was accomplished by a photometric method, by a Trim-Hill reaction. The content in total iridoids was expressed as aucubin equivalents (mg AEs)/g dw vegetal product [49].

\subsection{The Evaluation of Antioxidant Activity}

The assessment of the antiradical effect of Ajuga genevensis (Ag1) and A. reptans (Ar1) extracts was performed applying three methods: DPPH, ABTS radical scavenging and electron paramagnetic resonance (EPR) spectroscopy assays and described in previous papers $[12,47,50]$. The antioxidant capacity was expressed as $\mathrm{IC}_{50}(\mu \mathrm{g} / \mathrm{mL})$ for DPPH and as Trolox equivalents (TEs)/g of extract for ABTS assay and the positive control used in antioxidant methods was Trolox.

An $\mathrm{IC}_{50}$ value less than $50 \mu \mathrm{g}$ TEs/mL could indicate a very good antioxidant effect, the value between 50 and $100 \mu \mathrm{g}$ TEs/mL might show a valuable antioxidant effect, between 100 and $200 \mu \mathrm{g}$ $\mathrm{TEs} / \mathrm{mL}$ could reveal a soft antioxidant effect, while a value greater than $200 \mu \mathrm{g}$ TEs $/ \mathrm{mL}$ could mean the lack of antioxidant effect [51].

The antioxidant effect of Ajuga genevensis (Ag1) and A. reptans (Ar1) ethanol extracts was also evaluated by electron paramagnetic resonance (EPR), as previously described [52,53]. A control reaction was used in order to calculate the antiradical potential of extracts (expressed as Fremy's salt equivalents (FSE)/g dw).

\subsection{Qualitative and Quantitative Analysis of Polyphenols}

\subsubsection{Working Conditions-General Apparatus}

For the identification and quantification of the polyphenolic compounds the following system was employed: Agilent 1100 HPLC Series (Agilent Technologies, Santa Clara, CA, USA), to which a mass spectrometer Agilent Ion Trap SL was coupled, the latter being equipped with an atmospheric pressure chemical ionization (APCI) ion source or electrospray ionization (ESI).

\subsubsection{Polyphenolic Compounds Analysis-Chromatographic Conditions}

The Agilent 1100 HPLC Series system with UV detector, column thermostat, binary gradient pump and autosampler was employed. The HPLC system was coupled with an Agilent 1100 MS with ESI interface. A C18 RP Zorbax SB $(100 \times 3.0 \mathrm{~mm}, 3.5 \mu \mathrm{m})$ column was employed. The qualitative and quantitative analysis of polyphenols was carried out [12].The column temperature was set at $48{ }^{\circ} \mathrm{C}$. The mobile phase was a binary gradient obtained from methanol and solution of $0.1 \%$ acetic acid $(v / v)$. The elution started with a linear gradient for 35 minutes (from $5 \%$ to $42 \%$ methanol) and isocratic elution followed for the next $3 \mathrm{~min}$ ( $42 \%$ methanol). The solvent flow rate was maintained at 
$1 \mathrm{~mL} / \mathrm{min}$, the injection volume was $5 \mu \mathrm{L}$. The compounds' detection was carried out on UV and MS mode. The UV detector was set at $330 \mathrm{~nm}$ until $17.5 \mathrm{~min}$, then at $370 \mathrm{~nm}$. The polyphenols eluted in less than $35 \mathrm{~min}$. The collection and processing of chromatographic was done by Data Analysis and ChemStation software (Agilent Inc., Santa Clara, CA, USA).

\subsubsection{Mass Spectrometry Analysis}

The mass spectra signal was employed solely for identification, using the MS specific for each substance. All spectra were collected using a standard solution of polyphenols and integrated in a library. The compounds identified from MS detection were quantified by the UV trace (UV assisted by MS). The working conditions were: nitrogen temperature $350{ }^{\circ} \mathrm{C}$ at a flow rate of $12 \mathrm{~L} / \mathrm{min}$, nebulizer pressure $60 \mathrm{psi}$ and capillary voltage $+3000 \mathrm{~V}$. The detection limits were calculated as minimal concentration producing a reproductive peak with a signal-to-noise ratio greater than three. Retention times were determined with a standard deviation ranging from 0.04 to $0.19 \mathrm{~min}$. Accuracy was checked by spiking samples with a solution containing each polyphenol $(10 \mu \mathrm{g} / \mathrm{mL})$.

For the quantification of polyphenolic compounds, the external standard method was employed. For the identification of polyphenols, the recorded ESI-MS and their retention times (RT) were compared to those of standards, obtained under identical conditions [38,54]. The calibration curves for a five point plot were linear in the range $0.5-50 \mu \mathrm{g} / \mathrm{mL}\left(R^{2}>0.999\right)$ were further used for quantification of polyphenolic compounds in each extract.

\subsection{Qualitative and Quantitative Analysis of Phytosterolic Compounds}

Compounds separation was done under isocratic conditions with Zorbax SB-C18 RP analytical column $(100 \times 3.0 \mathrm{~mm}$ i.d., $5 \mu \mathrm{m})$ and methanol:acetonitrile 10:90 $(v / v)$ as mobile phase. The apparatus for MS analyses was Agilent Ion Trap 1100 SL MS with APCI interface, performing in positive ion mode.

The conditions were improved in order to achieve maximum sensitivity values: nitrogen temperature $325^{\circ} \mathrm{C}$ at a flow rate of $7 \mathrm{~L} / \mathrm{min}$, nebulizer pressure $60 \mathrm{psi}$ and capillary voltage $-4000 \mathrm{~V}$.

For sterols' identification, the RTs and MS were compared with those of standard compounds obtained under identical conditions. Instead of single ion monitoring mode (MS), the multiple reactions monitoring analysis mode was employed (MS/MS), to reduce the background's interference. A very good linearity for calibration curves $\left(R^{2}>0.998\right)$ and detection limits between $59-2808 \mathrm{ng} / \mathrm{mL}$ for campesterol, $69-3312 \mathrm{ng} / \mathrm{mL}$ for ergosterol, $132-6336 \mathrm{ng} / \mathrm{mL}$ for $\beta$-sitosterol, $62-2952 \mathrm{ng} / \mathrm{mL}$ for brassicasterol and 136-6528 ng/mL for stigmasterol were obtained.

In order to acquire and analyse the chromatographic data, Data Analysis (v5.3) and ChemStation (vA09.03) software from Agilent Inc., (USA) were used [54].

\subsection{Qualitative and Quantitative Analysis of Iridoids}

The LC-ESI-MS/MS determination of iridoids was completed with an Agilent 1100 model coupled to an Agilent Ion Trap 1100 SL MS. An Atlantis HILIC column $(100 \mathrm{~mm} \times 3.0 \mathrm{~mm}, 3.5 \mu \mathrm{m})$ was used. A binary gradient system with eluent (A) $0.1 \%$ acetic acid and $20 \mu \mathrm{M}$ sodium acetate in water, eluent (B) $0.1 \%$ acetic acid and $20 \mu \mathrm{M}$ sodium acetate in acetonitrile, with the gradient of $95-80 \% \mathrm{~B}(0-5 \mathrm{~min})$ represented the mobile phase. Data Analysis software (version B01.03, Agilent Inc., USA) was used to acquire and analyse the chromatographic data.

The MS with an ESI source worked with a scan range $m / z$ between 360-680, in positive mode. By using the previously described LC-ESI-MS/MS method [12], the following iridoids were identified considering the adducts formed with sodium $(M+23 \mathrm{~m} / \mathrm{z})$ : 8-O-acetylharpagide $(429.3 \mathrm{~m} / \mathrm{z})$, harpagoside $(517.4 \mathrm{~m} / \mathrm{z})$, harpagide $(387.2 \mathrm{~m} / \mathrm{z})$, catalpol $(385 \mathrm{~m} / \mathrm{z})$, aucubin $(369 \mathrm{~m} / \mathrm{z})$. Their identification was confirmed by comparing the data with standards under identical chromatographic conditions. The working parameters were: drying gas flow (Nitrogen) $12 \mathrm{~L} / \mathrm{min}, 30{ }^{\circ} \mathrm{C}$ capillary temperature and a nebulizer pressure of $60 \mathrm{psi}$. The determination coefficient for the calibration curves was $R^{2} \geq 0.990$. All phytochemical analyses were done in triplicate. 


\subsection{The Evaluation of Antibacterial Activity}

For the assessment of antibacterial potential, the following Gram + bacteria (Listeria monocytogenes, ATCC 19114, Staphylococcus aureus, ATCC 49444) and Gram - bacteria (Salmonella typhimurium, ATCC 14028, Pseudomonas aeruginosa, ATCC 27853, Escherichia coli, ATCC 25922) obtained from USAMV Cluj Napoca (Food Biotechnology Laboratory) were employed. The experiments were performed at $4{ }^{\circ} \mathrm{C}$ using Muller-Hinton Agar.

An adjusted microdilution method was used $[12,47]$ to determine the antibacterial effects of plants extracts. The determination of minimum inhibitory concentrations (MICs) was performed by dilution method with 96 multi-well plates. Different extract concentrations from Ajuga genevensis (Ag1) and A. reptans (Ar1) aerial parts were mixed with $10 \mu \mathrm{L}$ of inoculum and $100 \mu \mathrm{L}$ of Tryptic Soy Broth, followed by incubation for $24-48 \mathrm{~h} 37^{\circ} \mathrm{C}$. The lowest drug amount which could prevent the change of colour represented MIC, whereas the lowest concentration which indicates $99.5 \%$ killing of the original inoculum represents the minimum bactericidal concentration (MBC). Standard antibiotic Gentamycin $(4 \mu \mathrm{g} / \mathrm{mL}, 25 \mu \mathrm{L} /$ well) was employed as positive control, whereas $50 \%$ ethanol represented the negative control. The analyses were done three times, followed by calculation of the averages [47].

\subsection{The Evaluation of Antifungal Activity}

Five fungi (Penicillium funiculosum ATCC 56755, Candida parapsilosis ATCC 22019, Candida albicans ATCC 10231, Aspergillus niger ATCC 6275, Aspergillus flavus ATCC 9643) from USAMV Cluj Napoca (Food Biotechnology Laboratory) were used to evaluate the antifungal effects of Ajuga genevensis (Ag1) and $A$. reptans (Ar1) extracts. The microdilution method detailed in our previous paper [12] allowed the calculation of minimum inhibitory concentration (MIC) and respectively minimum fungicidal concentration (MFC). For ethanol, chloroform and petroleum ether extracts of Ajuga genevensis (Ag1) and $A$. reptans (Ar1) we determined the MICs and MFCs and the positive control was Fluconazole. The experiments were repeated three times and done in duplicate [55].

\subsection{The Evaluation of In Vivo Anti-Inflammatory Activity}

\subsubsection{Experimental Protocol}

Experimental groups consisted of Wistar albino rats obtained from the Animal Centre (Iuliu Haţieganu University of Medicine and Pharmacy Cluj-Napoca) (200-250 g). The animals (strain Crl:WI) with water ad libitum and standard pellet diet were housed prior to the experiments under a $12 \mathrm{~h}$ light/12 h dark cycle.

For the evaluation of anti-inflammatory effects in vivo, 9 groups consisting of 5 animals were used, to receive the following: (1) $0.9 \%$ saline solution $(1 \mathrm{~mL}$, i.m. and $1 \mathrm{~mL}$, i.p., negative control group), (2) turpentine oil (i.m., $6 \mathrm{~mL} / \mathrm{kg} \mathrm{BW}$ ) and $0.9 \%$ saline solution $(1 \mathrm{~mL}$, i.p.) (inflammation group), (3) turpentine oil (i.m., $6 \mathrm{~mL} / \mathrm{kg} \mathrm{BW)} \mathrm{and} 25 \mathrm{mg} \mathrm{dw} / \mathrm{mL}$ Ajuga genevensis (Ag1) ethanol extract (5 mL/kg BW), (4) turpentine oil (i.m., $6 \mathrm{~mL} / \mathrm{kg} \mathrm{BW})$ and $50 \mathrm{mg} \mathrm{dw} / \mathrm{mL} A g 1$ ethanol extract $(5 \mathrm{~mL} / \mathrm{kg}$ BW), (5) turpentine oil (i.m., $6 \mathrm{~mL} / \mathrm{kg} \mathrm{BW}$ ) and $100 \mathrm{mg} \mathrm{dw} / \mathrm{mL} A g 1$ ethanol extract ( $5 \mathrm{~mL} / \mathrm{kg} \mathrm{BW}$ ), (6) turpentine oil (i.m., $6 \mathrm{~mL} / \mathrm{kg} \mathrm{BW}$ ) and $25 \mathrm{mg} \mathrm{dw} / \mathrm{mL}$ Ajuga reptans (Ar1) ethanol extract ( $5 \mathrm{~mL} / \mathrm{kg} \mathrm{BW)}$ ), (7) turpentine oil (i.m., $6 \mathrm{~mL} / \mathrm{kg} \mathrm{BW)} \mathrm{and} 50 \mathrm{mg} \mathrm{dw} / \mathrm{mL}$ Ar1 ethanol extract ( $5 \mathrm{~mL} / \mathrm{kg} \mathrm{BW}$ ), (8) turpentine oil (i.m., $6 \mathrm{~mL} / \mathrm{kg} \mathrm{BW)} \mathrm{and} 100 \mathrm{mg} \mathrm{dw} / \mathrm{mL}$ Ar1 ethanol extract ( $5 \mathrm{~mL} / \mathrm{kg} \mathrm{BW),} \mathrm{(9)} \mathrm{turpentine} \mathrm{oil} \mathrm{(i.m.,}$ $6 \mathrm{~mL} / \mathrm{kg} \mathrm{BW})$, diclofenac (20 mg/kg BW) [12,56].

All treatments that involved animals were rigorously in accordance with EU Directive 2010/63/EU (European guidelines and rules). The Research Ethics Committee from Iuliu Haţieganu University of Medicine and Pharmacy Cluj-Napoca approved the research protocol (No. 382/2017).

The animals were anesthetized ( $20 \mathrm{mg} / \mathrm{kg}$ BW xylazine, $50 \mathrm{mg} / \mathrm{kg}$ BW ketamine), their blood collected and the obtained serum kept at $-80^{\circ} \mathrm{C}$ [57]. Afterwards, the rats were sacrificed by cervical dislocation [58]. 
Several parameters were determined: serum total nitrites and nitrates (NOx), total antioxidant response (TAR), oxidative stress index (OSI), total oxidative status (TOS). All experiments mentioned above were done in triplicate.

\subsubsection{The Evaluation of Phagocytic Capacity}

The determination of phagocytic capacity was performed as stated previously [59]. Phagocytic activity (the number of E. coli bacteria phagocytized by 100 leukocytes, PA) and phagocytic index (the percentage of leukocytes which phagocytized at most one bacterium, PI) were calculated.

\subsubsection{The Determination of White Blood Cells (WBC)}

The WBC count was realized in a counting chamber type Bürcker-Türk, with an Olympus optical microscope. The polymorphonuclear leukocytes (PMN) and monocytes (MO) were calculated as percentage [12].

\subsubsection{The Assessment of Oxidative Stress}

In order to calculate the NO synthesis (NOx), we evaluated the NOx content using a Griess reaction [60], determined as $\mu \mathrm{mol}$ nitrite/L. Spectrophotometric methods were employed to determine the total oxidative status (TOS, $\mu \mathrm{mol} \mathrm{H}_{2} \mathrm{O}_{2}$ equivalents/L) [61] and the total antioxidant response (TAR, $\mu \mathrm{mol} \mathrm{TE} / \mathrm{L}$ [62], whereas OSI was calculated as ratio TOS / TAR, as reported [63]. A spectrophotometer UV-VIS Jasco V-530 (Jasco International Co., Ltd., Tokyo, Japan) was employed.

\subsection{Statistical Analysis}

The analyses were performed in triplicate and the obtained results were expressed as mean \pm SD for each sample. Analysis of variance (ANOVA) was used to determine significant differences between values $(p<0.05)$, followed by multiple comparisons with Tukey test. The statistical significance of differences between extracts were evaluated by SPSS 16.0 for Windows (SPSS Inc, Chicago, IL, USA). Statistical correlations between data were calculated using the correlation analyses Pearson and Spearman.

\section{Conclusions}

In this research, two selected Romanian Ajuga species were evaluated for in vivo anti-inflammatory, antimicrobial and antioxidant activities, as well as for their composition in bioactive compounds. The most abundant compounds identified in the aerial parts of Ajuga reptans were isoquercitrin $\beta$-sitosterol and 8-O-acetylharpagide. The presence of these active substances may be associated with assessed biological activities. Using various methods, the antioxidant effect of Ajuga reptans and Ajuga genevensis extracts was evaluated and good antiradical capacities were evidenced, depending firstly on the nature of the extraction solvent and secondly on the different harvesting time and place. The antimicrobial assays revealed that Ajuga reptans petroleum ether extract presented potent activity against $A$. niger and $C$. albicans. The exhibited antifungal effects might be due to the presence of phytochemicals, primarily to 8 -O-acetylharpagide, the main iridoid glycoside. By monitoring some inflammation parameters, it was possible to determine the in vivo anti-inflammatory activity and a probable mechanism of action could be suggested with the help of these findings. The Ajuga reptans $100 \mathrm{mg} \mathrm{dw} / \mathrm{mL}$ extract displays important anti-inflammatory effects by reducing NO synthesis and it was comparable with those determined by diclofenac. The results indicate variations between the Ajuga species extracts, therefore, the necessity of selecting not only the proper solvent but also the appropriate harvesting time of plant material, to extract the highest possible amounts of phytochemicals. The anti-inflammatory effect of Ajuga reptans and A. genevensis ethanol extracts was observed by decreasing the oxidative stress, phagocytosis, PMN and total leukocytes. The Ajuga reptans $25 \mathrm{mg} \mathrm{dw} / \mathrm{mL}$ and $100 \mathrm{mg} \mathrm{dw} / \mathrm{mL}$ extracts presented higher anti-oxidant and anti-inflammatory 
activities, comparable with diclofenac. These findings support the usage of Ajuga reptans and Ajuga genevensis as anti-inflammatory agents in ethnobotanical medicine. Also, the results indicate that both selected Ajuga species have the potential to be valued as an important source of bioactive compounds in new herbal preparations with anti-inflammatory activity. Further in vivo experiments are recommended in order to develop effective and safe medicine-based phytopharmaceuticals.

Author Contributions: A.T., A.M., L.V., A.E.P., D.C.V., A.-M.G. and I.O. conceived and designed the structure of the manuscript and data collection. A.T., A.M., C.M. and A.E.P. drafted and revised the manuscript. A.T., A.M. and I.O. critically reviewed the manuscript. All authors have seen and agreed on the final version of the manuscript.

Funding: This research was funded by UEFISCDI, Romania, project no. PNII-RU-TE-2014-4-1247.

Conflicts of Interest: The authors declare no conflict of interest.

\section{References}

1. Atanasov, A.G.; Waltenberger, B.; Pferschy-Wenzig, E.M.; Linder, T.; Wawrosch, C.; Uhrin, P.; Temml, V.; Wang, L.; Schwaiger, S.; Heiss, E.H.; et al. Discovery and resupply of pharmacologically active plant-derived natural products: A review. Biotechnol. Adv. 2015, 33, 1582-1614. [CrossRef]

2. Shahidi, F.; Ambigaipalan, P. Phenolics and polyphenolics in foods, beverages and spices: Antioxidant activity and health effects-A review. J. Funct. Foods 2015, 18, 820-897. [CrossRef]

3. Abuajah, C.I.; Ogbonna, A.C.; Osuji, C.M. Functional components and medicinal properties of food: A review. J. Food Sci. Technol. 2015, 52, 2522-2529. [CrossRef] [PubMed]

4. Weihrauch, J.L.; Gardner, J.M. Sterol content of foods of plant origin. J. Am. Diet. Assoc. 1978, 73, 39-47.

5. Law, M. Plant sterol and stanol margarines and health. BMJ 2000, 320, 861-864. [CrossRef]

6. Moreau, R.A.; Whitaker, B.D.; Hicks, K.B. Phytosterols, phytostanols and their conjugates in foods: Structural diversity, quantitative analysis and health-promoting uses. Prog. Lipid Res. 2002, 41, 457-500. [CrossRef]

7. Ostlund, R.E. Phytosterols in human nutrition. Annu. Rev. Nutr. 2002, 22, 533-549. [CrossRef]

8. Riaz, N.; Nawaz, S.A.; Mukhtar, N.; Malik, A.; Afza, N.; Ali, S.; Ullah, S.; Muhammad, P.; Choudhary, M.I. Isolation and enzyme-inhibition studies of the chemical constituents from Ajuga bracteosa. Chem. Biodivers. 2007, 4, 72-83. [CrossRef]

9. Atay, I.; Kirmizibekmez, H.; Kaiser, M.; Akaydin, G.; Yesilada, E.; Tasdemir, D. Evaluation of in vitro antiprotozoal activity of Ajuga laxmannii and its secondary metabolites. Pharm. Biol. 2016, 54, 1808-1814. [CrossRef] [PubMed]

10. Cocquyt, K.; Cos, P.; Herdewijn, P.; Maes, L.; Van Den Steen, P.E.; Laekeman, G. Ajuga remota Benth.: From ethnopharmacology to phytomedical perspective in the treatment of malaria. Phytomedicine 2011, 18, 1229-1237. [CrossRef]

11. Gautam, R.; Jachak, S.M.; Saklani, A. Anti-inflammatory effect of Ajuga bracteosa Wall Ex Benth. mediated through cyclooxygenase (COX) inhibition. J. Ethnopharmacol. 2011, 133, 928-930. [CrossRef]

12. Toiu, A.; Mocan, A.; Vlase, L.; Pârvu, A.E.; Vodnar, D.C.; Gheldiu, A.M.; Moldovan, C.; Oniga, I. Phytochemical composition, antioxidant, antimicrobial and in vivo anti-inflammatory activity of traditionally used Romanian Ajuga laxmannii (Murray) Benth. ("nobleman's beard"-barba împăratului). Front. Pharmacol. 2018, 9, 1-15. [CrossRef]

13. Venditti, A.; Frezza, C.; Maggi, F.; Lupidi, G.; Bramucci, M.; Quassinti, L.; Giuliani, C.; Cianfaglione, K.; Papa, F.; Serafini, M.; et al. Phytochemistry, micromorphology and bioactivities of Ajuga chamaepitys (L.) Schreb. (Lamiaceae, Ajugoideae): Two new harpagide derivatives and an unusual iridoid glycosides pattern. Fitoterapia 2016, 113, 35-43. [CrossRef]

14. El-Hilaly, J.; Tahraoui, A.; Israili, Z.H.; Lyoussi, B. Hypolipidemic effects of acute and sub-chronic administration of an aqueous extract of Ajuga iva L. whole plant in normal and diabetic rats. J. Ethnopharmacol. 2006, 105, 441-448. [CrossRef]

15. Kayani, W.K.; Dilshad, E.; Ahmed, T.; Ismail, H.; Mirza, B. Evaluation of Ajuga bracteosa for antioxidant, anti-inflammatory, analgesic, antidepressant and anticoagulant activities. BMC Complement. Altern. Med. 2016, 16, 1-13. [CrossRef] 
16. Ono, Y.; Fukaya, Y.; Imai, S.; Yamakuni, T. Beneficial Effects of Ajuga decumbens on Osteoporosis and Arthritis. Biol. Pharm. Bull. 2008, 31, 1199-1204. [CrossRef]

17. Israili, Z.H.; Lyoussi, B. Ethnopharmacology of the plants of genus Ajuga. Pak. J. Pharm. Sci. 2009, 22, 425-462.

18. Jakovljević, D.Z.; Vasić, S.M.; Stanković, M.S.; Čomić, L.R.; Topuzović, M.D. Secondary metabolite content and in vitro biological effects of Ajuga chamaepitys (L.)Schreb. subsp. chamaepitys. Arch. Biol. Sci. 2015, 67, 1195-1202. [CrossRef]

19. Manguro, L.O.A.; Lemmen, P.; Hao, P. Iridoid glycosides from underground parts of Ajuga remota. Rec. Nat. Prod. 2011, 5, 147-157.

20. Movahhedin, N.; Zengin, G.; Bahadori, M.B.; Sarikurkcu, C.; Bahadori, S.; Dinparast, L. Ajuga chamaecistus subsp. scoparia (Boiss.) Rech.f.: A new source of phytochemicals for antidiabetic, skin-care and neuroprotective uses. Ind. Crops Prod. 2016, 94, 89-96. [CrossRef]

21. Ono, M.; Furusawa, C.; Ozono, T.; Oda, K.; Yasuda, S.; Okawa, M.; Kinjo, J.; Ikeda, T.; Miyashita, H.; Yoshimitsu, H.; et al. Four new iridoid glucosides from Ajuga reptans. Chem. Pharm. Bull. 2011, 59, 1065-1068. [CrossRef]

22. Toiu, A.; Vlase, L.; Arsene, A.L.; Vodnar, D.C.; Oniga, I. LC/UV/MS PROFILE OF POLYPHENOLS, ANTIOXIDANT AND ANTIMICROBIAL EFFECTS OF AJUGA GENEVENSIS L. EXTRACTS. Farmacia 2016, 64, 53-57.

23. Toiu, A.; Vlase, L.; Gheldiu, A.M.; Vodnar, D.; Oniga, I. EVALUATION OF THE ANTIOXIDANT AND ANTIBACTERIAL POTENTIAL OF BIOACTIVE COMPOUNDS FROM AJUGA REPTANS EXTRACTS. Farmacia 2017, 65, 351-355.

24. Liu, W.; Dongxue, Y.; Li, N.; Xiaogai, H.; Dongmei, W.; Li, D.; Liu, J. Influence of Environmental Factors on the Active Substance Production and Antioxidant Activity in Potentilla fruticosa L. and Its Quality Assessment. Sci. Rep. 2016, 1-18. [CrossRef]

25. Vittori, L.D.; Mazzoni, L.; Battino, M.; Mezzetti, B. Pre-harvest factors in fl uencing the quality of berries. Sci. Hortic. (Amsterdam). 2018, 233, 310-322. [CrossRef]

26. Rani, R.; Khan, M.A.; Kayani, W.K.; Ullah, S.; Naeem, I.; Mirza, B. Metabolic signatures altered by in vitro temperature stress in Ajuga bracteosa Wall. ex. Benth. Acta Physiol. Plant. 2017, 39. [CrossRef]

27. Aidi Wannes, W.; Mhamdi, B.; Sriti, J.; Ben Jemia, M.; Ouchikh, O.; Hamdaoui, G.; Kchouk, M.E.; Marzouk, B. Antioxidant activities of the essential oils and methanol extracts from myrtle (Myrtus communis var. italica L.) leaf, stem and flower. Food Chem. Toxicol. 2010, 48, 1362-1370. [CrossRef]

28. Chua, L.S.; Lau, C.H.; Chew, C.Y.; Ismail, N.I.M.; Soontorngun, N. Phytochemical profile of Orthosiphon aristatus extracts after storage: Rosmarinic acid and other caffeic acid derivatives. Phytomedicine 2018, 39, 49-55. [CrossRef]

29. Grubešić, R.J.; Vuković, J.; Kremer, D.; Vladimir-Knežević, S. Spectrophotometric method for polyphenols analysis: Prevalidation and application on Plantago L. species. J. Pharm. Biomed. Anal. 2005, 39, 837-842. [CrossRef]

30. Piekarska, J.; Szczypka, M.; Kucharska, A.Z.; Gorczykowski, M. Effects of iridoid-anthocyanin extract of Cornus mas L. on hematological parameters, population and proliferation of lymphocytes during experimental infection of mice with Trichinella spiralis. Exp. Parasitol. 2018, 188, 58-64. [CrossRef]

31. Valentová, K.; Vrba, J.; Bancírová, M.; Ulrichová, J.; Křen, V. Isoquercitrin: Pharmacology, toxicology and metabolism. Food Chem. Toxicol. 2014, 68, 267-282. [CrossRef]

32. Ghita, G.; Cioanca, O.; Gille, E.; Necula, R.; Zamfirache, M.M.; Stanescu, U. CONTRIBUTIONS TO THE PHYTOCHEMICAL STUDY OF SOME SAMPLES OF AJUGA REPTANS L. AND AJUGA GENEVENSIS L. Bull. Transilv. Univ. Brasov 2011, 4, 7-14.

33. Mamadalieva, N.Z.; El-readi, M.Z.; Ovidi, E.; Ashour, M.L.; Hamoud, R.; Sagdullaev, S.S.; Azimova, S.S.; Tiezzi, A.; Wink, M. Antiproliferative, antimicrobial and antioxidant activities of the chemical constituents of Ajuga turkestanica. Phytopharmacology 2013, 4, 1-18.

34. Manguro, L.O.A.; Otieno, S.; Lemmen, P. Flavonol and iridoid glycosides of Ajuga remota aerial parts. J. Asian Nat. Prod. Res. 2006, 67, 830-837. [CrossRef]

35. Hailu, W.; Engidawork, E. Evaluation of the diuretic activity of the aqueous and $80 \%$ methanol extracts of Ajuga remota Benth (Lamiaceae) leaves in mice. BMC Complement. Altern. Med. 2014, 14, 135. [CrossRef] 
36. Makni, M.; Haddar, A.; Kriaa, W.; Zeghal, N. Antioxidant, free radical scavenging and antimicrobial activities of Ajuga iva leaf extracts. Int. J. Food Prop. 2013, 16, 756-765. [CrossRef]

37. Kawamura, F.; Ohara, S. Antifungal activity of iridoid glycosides from the heartwood of Gmelina arborea. Holzforschung 2005, 59, 153-155. [CrossRef]

38. Andriamadio, J.H.; Rasoanaivo, L.H.; Benedec, D.; Vlase, L.; Gheldiu, A.M.; Duma, M.; Toiu, A.; Raharisololalao, A.; Oniga, I. HPLC/MS analysis of polyphenols, antioxidant and antimicrobial activities of Artabotrys hildebrandtii O. Hffm. extracts. Nat. Prod. Res. 2015, 29, 2188-2196. [CrossRef]

39. Salvat, A.; Antonacci, L.; Fortunato, R.H.; Suarez, E.Y.; Godoy, H.M. Antimicrobial activity in methanolic extracts of several plant species from northern Argentina. Phytomedicine 2004, 11, 230-234. [CrossRef]

40. Alves, M.J.; Ferreira, I.C.F.R.; Froufe, H.J.C.; Abreu, R.M.V.; Martins, A.; Pintado, M. Antimicrobial activity of phenolic compounds identified in wild mushrooms, SAR analysis and docking studies. J. Appl. Microbiol. 2013, 115, 346-357. [CrossRef]

41. Stojković, D.; Petrović, J.; Soković, M.; Glamočlija, J.; Kukić-Marković, J.; Petrović, S. In situ antioxidant and antimicrobial activities of naturally occurring caffeic acid, p-coumaric acid and rutin, using food systems. J. Sci. Food Agric. 2013, 93, 3205-3208. [CrossRef]

42. Halliwell, B. The antioxidant paradox: less paradoxical now? Br. J. Clin. Pharmmacol. 2012, 75, 637-644. [CrossRef]

43. Biswas, S.K. Does the Interdependence between Oxidative Stress and Inflammation Explain the Antioxidant Paradox? Oxid. Med. Cell. Longev. 2016, 2016, 17-19. [CrossRef] [PubMed]

44. Kessler, M.; Ubeaud, G.; Jung, L. Anti- and pro-oxidant activity of rutin and quercetin derivatives. J. Pharm. Pharmacol. 2003, 55, 131-142. [CrossRef] [PubMed]

45. Denat, L.; Kadekaro, A.L.; Marrot, L.; Leachman, S. Melanocytes as Instigators and Victims of Oxidative Stress. J. Invest. Dermatol. 2014, 134, 1512-1518. [CrossRef] [PubMed]

46. Rauca, V.; Licarete, E.; Luput, L.; Sesarman, A.; Patras, L.; Bulzu, P.; Rakosy-tican, E.; Banciu, M. Combination therapy of simvastatin and 5, 6- dimethylxanthenone-4-acetic acid synergistically suppresses the aggressiveness of B16. F10 melanoma cells. PLoS ONE 2018, 13, e202827. [CrossRef] [PubMed]

47. Mocan, A.; Crişan, G.; Vlase, L.; Crişan, O.; Vodnar, D.C.; Raita, O.; Gheldiu, A.M.; Toiu, A.; Oprean, R.; Tilea, I. Comparative studies on polyphenolic composition, antioxidant and antimicrobial activities of schisandra chinensis leaves and fruits. Molecules 2014, 19, 15162-15179. [CrossRef] [PubMed]

48. Tămaş, M.; Toiu, A.; Oniga, I.; Deliu, C.; Oltean, B.; Coldea, G. Quantitative determination of total polyphenols and flavonoids from indigenous species of Epilobium of wild origin and "in vitro" regenerated plantlets. Contrib. Bot. 2009, 44, 119-123.

49. Erdenechimeg, C.; Guiqide, A.; Dejidmaa, B.; Chimedragchaa, C.; Purevsuren, S. Total phenolic, flavonoid, alkaloid and iridoid content and preventive effect of Lider-7-tang on lipopolysaccharide-induced acute lung injury in rats. Brazilian J. Med. Biol. Res. 2017, 50, 6-11. [CrossRef] [PubMed]

50. Zengin, G.; Uysal, A.; Gunes, E.; Aktumsek, A. Survey of phytochemical composition and biological effects of three extracts from a wild plant (Cotoneaster nummularia Fisch. et Mey.): A potential source for functional food ingredients and drug formulations. PLoS ONE 2014, 9. [CrossRef] [PubMed]

51. Araniciu, C.; Parvu, A.E.; Palage, M.D.; Oniga, S.D.; Benedec, D.; Oniga, I.; Oniga, O. The Effect of Some 4,2 and 5,2 Bisthiazole Derivatives on Nitro-Oxidative Stress and Phagocytosis in Acute Experimental Inflammation. Molecules 2014, 19, 9240-9256. [CrossRef]

52. Barakat, H.; Rohn, S. Effect of different cooking methods on bioactive compounds in vegetarian, broccoli-based bars. J. Funct. Foods 2014, 11, 407-416. [CrossRef]

53. Moussa-Ayoub, T.E.; Abd El-Hady, E.S.A.; Omran, H.T.; El-Samahy, S.K.; Kroh, L.W.; Rohn, S. Influence of cultivar and origin on the flavonol profile of fruits and cladodes from cactus Opuntia ficus-indica. Food Res. Int. 2014, 64, 864-872. [CrossRef]

54. Vlase, L.; Parvu, M.; Parvu, E.A.; Toiu, A. Chemical constituents of three Allium species from romania. Molecules 2013, 18, 114-127. [CrossRef] [PubMed]

55. Stana, A.; Vodnar, D.C.; Tamaian, R.; Pîrnău, A.; Vlase, L.; Ionuț, I.; Oniga, O.; Tiperciuc, B. Design, synthesis and antifungal activity evaluation of new thiazolin-4-ones as potential lanosterol $14 \alpha$-demethylase inhibitors. Int. J. Mol. Sci. 2017, 18, 177. [CrossRef] [PubMed] 
56. Andreicut, A.; Pârvu, A.E.; Augustin, C.; Pârvu, M.; Fodor, E.F.; Florinela, A.; Feldrihan, V.; Cecan, M.; Irimie, A. Phytochemical Analysis of Anti-Inflammatory and Antioxidant Effects of Mahonia aquifolium Flower and Fruit Extracts. Oxid. Med. Cell. Longev. 2018, 2018, 1-12. [CrossRef] [PubMed]

57. Parvu, A.E.; Parvu, M.; Vlase, L.; Miclea, P.; Mot, A.C.; Silaghi-Dumitrescu, R. Anti-inflammatory effects of Allium schoenoprasum L. leaves. J. Physiol. Pharmacol. 2014, 65, 309-315.

58. Francischi, J.N.; Frade, T.I.C.; Almeida, M.P.A.d.; Queiroz, B.F.G.d.; Bakhle, Y.S. Ketamine-xylazine anaesthesia and orofacial administration of substance P: A lethal combination in rats. Neuropeptides 2017, 62, 21-26. [CrossRef]

59. Moldovan, C.M.; Oniga, O.; Pârvu, A.; Tiperciuc, B.; Verite, P.; Pîrnǎu, A.; Crişan, O.; Bojiţă, M.; Pop, R. Synthesis and anti-inflammatory evaluation of some new acyl-hydrazones bearing 2-aryl-thiazole. Eur. J. Med. Chem. 2011, 46, 526-534. [CrossRef] [PubMed]

60. Miranda, K.M.; Espey, M.G.; Wink, D.A. A Rapid, Simple Spectrophotometric Method for Simultaneous Detection of Nitrate and Nitrite. Nitric Oxide 2001, 5, 62-71. [CrossRef]

61. Erel, O. A new automated colorimetric method for measuring total oxidant status. Clin. Biochem. 2005, 38, 1103-11111. [CrossRef]

62. Erel, O. A novel automated method to measure total antioxidant response against potent free radical reactions. Clin. Biochem. 2004, 37, 112-119. [CrossRef]

63. Harma, M.; Harma, M.; Erel, O. Increased oxidative stress in patients with hydatidiform mole. Swiss Med. Wkly. 2003, 133, 563-566. [PubMed]

Sample Availability: No samples are available from the authors.

(C) 2019 by the authors. Licensee MDPI, Basel, Switzerland. This article is an open access article distributed under the terms and conditions of the Creative Commons Attribution (CC BY) license (http://creativecommons.org/licenses/by/4.0/). 